\title{
Modest Dietary Protein Requirement for Sea Urchin Gonad Production Demonstrated by Feeding Trials with Consideration of Protein Leaching
}

\author{
Satomi Takagi $\mathbb{D}^{1},{ }^{1}$ Kazuhiro Takahashi, ${ }^{2}$ Tomonori Kaneta, ${ }^{2}$ Akira Sugawara, \\ Masanao Narita, ${ }^{2}$ Shinji Kato, ${ }^{3}$ Masaki Akino, ${ }^{3}$ Hirofumi Takeda, ${ }^{3}$ Natsuki Hasegawa, ${ }^{1}$ \\ Yuji Machiguchi, ${ }^{4}$ and Tatsuya Unuma ${ }^{1}{ }^{1}$ \\ ${ }^{1}$ Kushiro Field Station, Fisheries Resources Institute, Japan Fisheries Research and Education Agency, Kushiro, \\ Hokkaido 085-0802, Japan \\ ${ }^{2}$ Central Fisheries Research Institute, Hokkaido Research Organization, Yoichi, Hokkaido 046-8555, Japan \\ ${ }^{3}$ Kushiro Fisheries Research Institute, Hokkaido Research Organization, Kushiro, Hokkaido 085-0027, Japan \\ ${ }^{4}$ Sapporo Field Station, Fisheries Resources Institute, Japan Fisheries Research and Education Agency, Sapporo, \\ Hokkaido 062-0922, Japan
}

Correspondence should be addressed to Tatsuya Unuma; unuma@fra.affrc.go.jp

Received 12 November 2021; Accepted 18 January 2022; Published 7 March 2022

Academic Editor: Erchao Li

Copyright $\odot 2022$ Satomi Takagi et al. This is an open access article distributed under the Creative Commons Attribution License, which permits unrestricted use, distribution, and reproduction in any medium, provided the original work is properly cited.

\begin{abstract}
This study is aimed at revealing the dietary protein requirement for gonad production in the sea urchin Mesocentrotus nudus, with consideration of protein leaching from diets during seawater immersion. Feeding trials were performed on $M$. nudus using two diet types with low capacities for protein leaching: starch diets (STG) containing 0-40\% gluten in 10\%, 5\%, and 4\% increments (experiments 1-3) and alginate diets (ALG) containing 5-25\% gluten in 5\% increments (experiment 4). The protein content in the diets was determined after they were immersed in seawater for $24 \mathrm{~h}$ or $72 \mathrm{~h}$. The gonad indices of urchins fed STG with 11.4-19.3\% protein were significantly higher than those fed STG with $7.8 \%$ protein. The protein requirement was estimated to be $12 \%$ based on a broken-line regression analysis of urchins fed STG in experiments $1-3$. In experiment 4 , the gonads became larger as dietary protein content increased from $4.5 \%$ to $12.0 \%$, and the sizes were similar to those of urchins fed ALG with $12.0-21.1 \%$ protein. The estimated value of $12 \%$ was much lower than that reported previously $(>20 \%)$, indicating that the protein requirement for sea urchin gonad production is modest when the protein-leaching problem is addressed.
\end{abstract}

\section{Introduction}

The global consumption of fish and shellfish increased from 69 million tons in 1991 to 132 million tons in 2013 [1], and it is predicted to reach 178 million tons by 2028 [2]. Sea urchin gonads are a luxury seafood with high commercial value [3]. The annual average price of sea urchin gonads at the Tokyo Metropolitan Central Wholesale Market, the largest sea urchin market in the world [4], has nearly doubled over the past decade [5]. In addition, the import of live, fresh, or chilled sea urchins to European and Oceanian countries has been occurring since 2012 [6], indicating that the worldwide demand for sea urchins has been increasing. However, a decrease in world sea urchin landings from 109,736 tons in 1995 to 75,637 tons in 2019 [7] because of stock depletion caused by overfishing [8] has promoted the need to produce hatchery-raised urchins in aquaculture systems $[9,10]$. Sea urchins densely distributed on "barrens" (e.g., $[11,12])$, where communities of crustose coralline red algae without erect macrophytes occur in subtidal rocky seafloors, exhibit decreased growth rate and have small gonads with inferior quality (e.g., $[13,14])$. Recently, utilization of barren individuals of Mesocentrotus nudus in Northern Japan [15-17], Heliocidaris erythrogramma in Australia 
[18-20], and Strongylocentrotus droebachiensis in Norway $[21,22]$ have been concentrated. In particular, M. nudus commands the highest price of all edible sea urchins around the world [23]. Previous studies have demonstrated that feeding M. nudus with cultivated kelp, specifically fresh Saccharina japonica fronds or Undaria pinnatifida sporophylls, can improve the quality of barren-collected sea urchin gonads, causing the improved gonads to be more desirable than the gonads of wild $M$. nudus with commercial value $[16,24]$. However, the potential of these kelps as sea urchin food depends on their nutritional content [24-27] which changes phenologically (e.g., [28-30]). Additionally, depending on the season and location, it can be difficult to collect a sufficient amount of kelp for sea urchin aquaculture. Therefore, the development of artificial feed is desirable to stabilize the nutritional value and to supply a substantial amount of sea urchin feed without seasonal and locational limitation.

Many studies have been conducted to develop artificial feeds for sea urchins such as Evechinus chloroticus (e.g., [31, 32]), H. erythrogramma [33], Loxechinus albus [34], Lytechinus variegatus (e.g., $[35,36])$, Mesocentrotus franciscanus [37-39], Paracentrotus lividus (e.g., [40, 41]), Psammechinus miliaris (e.g., [40, 42]), Pseudocentrotus depressus [43, 44], S. droebachiensis (e.g., [45-47]), Strongylocentrotus intermedius (e.g., [48, 49]), Strongylocentrotus purpuratus (e.g., [50, 51]), and Tripneustes gratilla (e.g., [52, 53]). In feeding trials that used artificial diets and macroalgae, artificial diets often induced faster growth of sea urchin gonads compared with Laminariales kelp [34, 54-56]. The authors of these studies suggested that the major cause of the high performance in gonad production was the high protein content of the artificial diets. The optimum dietary protein level for gonad production has been estimated to be over $20 \%$ for various sea urchin species [44, 46, 57-60]. This value is high compared to the protein content of kelp, which is typically $4-16 \%$ (e.g., $[61,62]$ ).

Like some gastropods and crustaceans, sea urchins have slower feeding behavior than fish. Accordingly, artificial feeds for these slow feeders must withstand disintegration and nutrient leaching while they are immersed in seawater $[63,64]$. For decades, the effects of the binder type and concentration on the shape stability and nutrient leaching of abalone and shrimp feeds have been intensively investigated to improve the feed quality (e.g., [63-65]). These studies have revealed that a portion of the protein included in the diets of abalone and shrimp can be lost due to leaching before the feed is consumed. For instance, after $12 \mathrm{~h}$ of immersion in water, abalone diets formulated with $20 \%$ starch as a binder lost $0-43 \%$ of their protein [66]. In that study, the degree of loss differed among protein sources, suggesting that the selection of protein sources as well as binders is important for reducing protein leaching. Compared to abalone and shrimp feeds, less attention has been paid to the problem of nutrient leaching in sea urchin diets, although Takagi, Murata, Koshiishi, and Agatsuma [24] reported that $50 \%$ of the crystalline amino acids supplemented in sea urchin diets was lost after $1 \mathrm{~h}$ of immersion in seawater. Taking these facts into consideration, the actual protein requirement of sea urchins might be lower than that which has been previously reported, as the protein contents in experimental diets were likely decreased due to leaching.

The aim of this study was to reveal the true dietary protein requirements for gonad production of adult $M$. nudus through feeding trials. To eliminate the problems of protein leaching in seawater, we undertook two approaches: (1) the protein source, binder source, and binder concentration in each experimental diet were selected to reduce disintegration and protein leaching as much as possible during seawater immersion; (2) the real protein contents of the diets were determined after the diets were immersed in seawater during feeding trials. Four independent feeding trials were conducted with $M$. nudus collected from a barren. In each experiment, M. nudus was fed diets with different protein levels, and gonad growth was compared among the treatments. To accurately estimate the protein requirement for gonad production, experiments 1-3 were designed to explore the effects of experimental diets with the same ingredients but different protein levels. The intervals of protein level among the treatments were narrowed step by step in the three experiments to highlight the protein requirement level, which was estimated based on the modeled relationship between the real protein content of the diets and the resulting gonad production in the three experiments. Experiment 4 was conducted using diets with a different binder source than those used in experiments 1-3 to investigate the effect of the binder source on the dietary protein requirement. We believe that this study will provide useful information for the development of sea urchin diets.

\section{Materials and Methods}

2.1. Selection of Diet Ingredients. To select ingredients for diets with high shape stability and low protein leaching during seawater immersion, a seawater immersion test was performed with 16 prepared diets that were formulated to examine three experimental factors: (1) binder source (starch, alginate, and agar), (2) protein source (gluten and casein), and (3) binder concentration (50\%, 15\%, and 5\%; percent dry weight of all dietary components) (Table S1). Diets with $50 \%$ agar were not prepared because of the difficulty in molding the feed. All the diets for the seawater immersion test contained $20 \%$ protein source and $10 \%$ powdered Saccharina japonica var. diabolica kelp, which was collected in Akkeshi Bay, Hokkaido $\left(43^{\circ} 01^{\prime} 17^{\prime \prime} \mathrm{N}\right.$, $144^{\circ} 50^{\prime} 12^{\prime \prime} \mathrm{E}$ ) on March 25, 2021. The diets were dried in an oven at $60^{\circ} \mathrm{C}$ for $>24 \mathrm{~h}$ and were then pulverized using a mill (Wonder Blender WB-1, Osaka Chemical Co., Ltd, Osaka, Japan). Cellulose was used to balance the three binder concentrations (see Figure S1 for more details on diet preparation). Except for S. japonica powder, all diet ingredients were reagent-grade. The crude protein contents of gluten, casein, and S. japonica powder, which were obtained according to the methods described in Section 2.5 , were $94.4 \%, 98.6 \%$, and $11.8 \%$, respectively. For brevity, diet names are abbreviated according to the binder type and protein source (starch, ST; alginate, AL; agar, AG; gluten, G; casein, C) and the binder concentration (5\%, 5; $15 \%, 15 ; 50 \%, 50$ ) (e.g., the diet with gluten and $50 \%$ 
starch is abbreviated as 50-STG). Diet samples were cut into $2 \mathrm{~mm} \times 25 \mathrm{~mm} \times 45 \mathrm{~mm}$ pieces and stored at $4^{\circ} \mathrm{C}$. To test the effects of storage temperature, twice as much 50-STG and 50-STC were prepared compared to the other diets, and half of each was stored in a $-80^{\circ} \mathrm{C}$ freezer (50-STG-F and 50-STC-F).

Four samples of each diet were immersed in running seawater at approximately $13^{\circ} \mathrm{C}$ and were collected after 24 or $72 \mathrm{~h}$. Photographs of each diet were taken on a white plate before and after $72 \mathrm{~h}$ of immersion using a digital camera (COOLPIX W150, Nikon, Tokyo, Japan) to compare diet stability. The diets before and after $24 \mathrm{~h}$ and $72 \mathrm{~h}$ immersion were lyophilized, pulverized, and studied for protein analysis, as described in Section 2.5.

Because of their high shape stability and low proteinleaching capacity, 50-STG and 50-ALG were used in experiments 1-3 and experiment 4, respectively (see details in Section 3.1.; Figures S2 and S3). The experimental diets were prepared in the same manner as the seawater immersion diets but with different proportions of gluten. The diets with $20 \%$ gluten were prepared for all four experiments in common.

2.2. Sea Urchin Collection. Adult M. nudus was collected from a barren by scuba diving at depths of 2-6 $\mathrm{m}$ in Yoichi Bay, Hokkaido $\left(43^{\circ} 12^{\prime} 26^{\prime \prime} \mathrm{N}, 140^{\circ} 46^{\prime} 38^{\prime \prime} \mathrm{E}\right)$ on March 10, 2020 (for experiment 3), October 27, 2020 (for experiment 1), and May 18, 2021 (for experiments 2 and 4). The collected urchins were transported to the Central Fisheries Research Institute of the Hokkaido Research Organization in Yoichi, Hokkaido $\left(43^{\circ} 12^{\prime} 14^{\prime \prime} \mathrm{N}, 140^{\circ} 46^{\prime} 29^{\prime \prime} \mathrm{E}\right)$, where they were reared in 1-ton tanks ( $>2.5 \mathrm{~L} /$ individual) that were aerated and supplied with sand-filtered seawater kept at 12$15^{\circ} \mathrm{C}(12 \mathrm{~L} / \mathrm{min} / \operatorname{tank}$, flow-through system $)$. Once a month, the sea urchins for experiment 1 were fed dried Saccharina longissima (purchased from a fish market, collected in Hokkaido; no detailed information of the collection site is available to us) to be consumed within five days, and those for experiment 2 were starved until the feeding trial. The urchins for experiments 3 and 4 were transported to the Kushiro Field Station of the Fishery Resources Institute in Kushiro, Hokkaido $\left(42^{\circ} 57^{\prime} 01^{\prime \prime} \mathrm{N}, 144^{\circ} 26^{\prime} 35^{\prime \prime} \mathrm{E}\right)$ on April 7, 2020 (experiment 3) and June 15, 2021 (experiment 4), respectively. They were reared in 2 -ton tanks $(>3.5 \mathrm{~L} /$ individual) that were aerated and supplied with sand-filtered seawater $(6 \mathrm{~L} / \mathrm{min} / \mathrm{tank}$, flow-through system) at an ambient temperature. Once a month, the sea urchins for experiment 3 were fed fresh Saccharina sp., which was collected in front of the Kushiro Field Station or in the Akkeshi Bay, to be consumed within five days. The sea urchins for experiment 4 were starved until the feeding trials. All feeding experiments were started between May and June, when the gonads of $M$. nudus accumulate nutrients into nutritive phagocytes (i.e., the nutrient storage cells in the gonad) [67].

\subsection{Feeding Trials with Starch Diets}

2.3.1. Experiment 1: STG Diets with 0-40\% Gluten (10\% Increments). Sea urchins were subjected to five feeding treatments with 50 -STG having $0 \%, 10 \%, 20 \%, 30 \%$, or $40 \%$ glu- ten (STG0, STG10, STG20, STG30, and STG40). This experiment was performed at the Central Fisheries Research Institute from May 7, 2021, to June 9, 2021 (33 days). Details on the diet composition are shown in Table 1 . The diets were prepared in the same manner with the seawater immersion test as described in 2.1 .

At the start of the experiment, 108 sea urchins $(37-46 \mathrm{~mm}$ test diameter, TD; $25-43 \mathrm{~g}$ body weight, $\mathrm{BW}$ ) were measured for TD with a vernier caliper $(0.01 \mathrm{~mm}$ accuracy) and for BW with an electronic balance ( $0.1 \mathrm{~g}$ accuracy). The sea urchins were divided into six groups, with each group consisting of individuals with similar BW variances and averages. One group was the initial control (IC1, 18 individuals) that consisted of individuals dissected at the start of the experiment, and the other groups were randomly allocated to the five treatments of the feeding trials (18 individuals/treatment). The urchins in each treatment were housed in three polypropylene cages (L $44 \times \mathrm{W} 32 \times \mathrm{D} 27 \mathrm{~cm}, 2 \times 1.2 \mathrm{~cm}$ open mesh on sides higher than $3 \mathrm{~cm}$ from the bottom) at a density of 6 individuals/cage. The 15 cages were randomly placed in two rectangular tanks (inside dimensions, L $180 \times \mathrm{W} 90 \times \mathrm{D} 70 \mathrm{~cm}$ ) that were aerated and supplied with sand-filtered seawater kept at approximately $13^{\circ} \mathrm{C}(4.5 \mathrm{~L} / \mathrm{min} / \mathrm{tank}, 15 \mathrm{~cm}$ depth, flow-through system). To eliminate the effects of the cage position, the location of each cage was rotated over the tanks every week. Each diet was prepared prior to feeding every 37 days (see Figure S1 for diet preparation) and cut into moist sheets with $2-3 \mathrm{~mm}$ thickness, $10-20 \mathrm{~mm}$ width, and 40 $70 \mathrm{~mm}$ length. The sea urchins were given an excess amount of the diet every 2-3 days so that they were able to eat until satiation. The uneaten food was collected immediately before replenishing with new food. The uneaten food was dried in an oven at $60^{\circ} \mathrm{C}$ for $>48 \mathrm{~h}$. The wet weight of the food given to the urchins and the dry weight of the uneaten food were measured for each cage using an electronic balance $(0.01 \mathrm{~g}$ accuracy).

To determine how the weight of each diet changed independently from the influence of sea urchin feeding, approximately $6 \mathrm{~g}$ of each diet was immersed in running seawater at $13^{\circ} \mathrm{C}$ for $48 \mathrm{~h}$ or $72 \mathrm{~h}(n=3$ for each). Then, the samples were dried in an oven at $60^{\circ} \mathrm{C}$ for $>48 \mathrm{~h}$. The weight change ratio of each diet was calculated by dividing the dry weight of the diet after immersion by the weight of the diet before immersion. The average weight change ratio of the diets after $48 \mathrm{~h}$ and $78 \mathrm{~h}$ of immersion was used to calculate the food intake for each cage, as follows:

$$
\text { Foodintake }(g)=\frac{\left(\mathrm{DW}_{\text {given }} \times R-\mathrm{DW}_{\text {left }}\right)}{\text { number of individuals in cage }},
$$

where $\mathrm{DW}_{\text {given }}$ is the total weight of diets given to the cage, $R$ is the weight change ratio, and $\mathrm{DW}_{\text {left }}$ is the total dry weight of uneaten diets left in the cage.

To determine the protein content of the diets after they were given to the urchins, a seawater immersion test was conducted for each diet, as described in Section 2.1. Briefly, 5-8 samples of each diet (approximately $10 \mathrm{~g}$ ) were immersed in seawater for $24 \mathrm{~h}$ or $72 \mathrm{~h}$. The diets before 
TABLE 1: Ingredient composition and protein content of the artificial diets fed to Mesocentrotus nudus in experiments 1-4.

\begin{tabular}{|c|c|c|c|c|c|c|c|c|}
\hline \multirow{2}{*}{ Treatment } & \multicolumn{5}{|c|}{ Ingredient composition (\%) } & \multirow{2}{*}{ Water (outer percentage) } & \multicolumn{2}{|c|}{ Protein content $(\%)$} \\
\hline & Starch $^{\mathrm{a}}$ & Alginate $^{b}$ & Gluten $^{c}$ & Kelp powder ${ }^{\mathrm{d}}$ & Cellulose $^{\mathrm{e}}$ & & Before immersion & After immersion $^{\mathrm{f}}$ \\
\hline \multicolumn{9}{|c|}{ Experiment 1} \\
\hline STG0 ${ }^{\mathrm{g}}$ & 50 & & 0 & 10 & 40 & 60 & 2.19 & 1.51 \\
\hline STG10 & 50 & & 10 & 10 & 30 & 60 & 10.97 & 9.51 \\
\hline STG20 & 50 & & 20 & 10 & 20 & 60 & 20.12 & 19.31 \\
\hline STG30 & 50 & & 30 & 10 & 10 & 60 & 30.34 & 28.88 \\
\hline STG40 & 50 & & 40 & 10 & 0 & 60 & 38.79 & 38.23 \\
\hline \multicolumn{9}{|c|}{ Experiment 2} \\
\hline STG5 & 50 & & 5 & 10 & 35 & 60 & 5.55 & 4.64 \\
\hline STG10 & 50 & & 10 & 10 & 30 & 60 & 9.94 & 8.78 \\
\hline STG15 & 50 & & 15 & 10 & 25 & 60 & 14.16 & 13.22 \\
\hline STG20 & 50 & & 20 & 10 & 20 & 60 & 18.42 & 17.34 \\
\hline STG25 & 50 & & 25 & 10 & 15 & 60 & 23.14 & 21.59 \\
\hline \multicolumn{9}{|c|}{ Experiment 3} \\
\hline STG8 & 50 & & 8 & 10 & 32 & 60 & 8.68 & 7.79 \\
\hline STG12 & 50 & & 12 & 10 & 28 & 60 & 12.28 & 11.41 \\
\hline STG16 & 50 & & 16 & 10 & 24 & 60 & 16.59 & 15.11 \\
\hline STG20 & 50 & & 20 & 10 & 20 & 60 & 20.12 & 19.31 \\
\hline STG24 & 50 & & 24 & 10 & 16 & 60 & 24.04 & 21.76 \\
\hline \multicolumn{9}{|c|}{ Experiment 4} \\
\hline ALG5 & & 50 & 5 & 10 & 35 & 60 & 4.61 & 4.26 \\
\hline ALG10 & & 50 & 10 & 10 & 30 & 60 & 8.93 & 8.36 \\
\hline ALG15 & & 50 & 15 & 10 & 25 & 60 & 13.12 & 12.00 \\
\hline ALG20 & & 50 & 20 & 10 & 20 & 60 & 17.53 & 16.22 \\
\hline ALG25 & & 50 & 25 & 10 & 15 & 60 & 21.20 & 21.05 \\
\hline
\end{tabular}

${ }^{a}$ Starch, from Potato, FUJIFILM Wako Pure Chemical Corporation, Osaka, Japan ( $\leq 100 \%$ purity). ${ }^{b}$ Sodium alginate, FUJIFILM Wako Pure Chemical corporation ( $\leq 100 \%$ purity). ${ }^{\mathrm{c}}$ Gluten, from wheat, FUJIFILM Wako Pure Chemical corporation ( $\leq 100 \%$ purity). ${ }^{\mathrm{d}}$ Saccharina japonica var. diabolica. ${ }^{\mathrm{e}}$ Crystalline cellulose, FD-301, CEOLUS ${ }^{\circledR}$, Asahi Kasei Corp., Tokyo, Japan ( $\leq 100 \%$ purity). ${ }^{\mathrm{f}}$ Mean value of $24 \mathrm{~h}$ and $72 \mathrm{~h}$ immersion. ${ }^{\mathrm{g}}$ Treatment names are abbreviated according to the binder and protein sources (starch: ST; alginate: AL; gluten: G) and the gluten concentration $(0-40 \%)$ in diets fed to sea urchins.

and after $24 \mathrm{~h}$ or $72 \mathrm{~h}$ of immersion were subjected to protein analysis as described in Section 2.5. The average protein content in the diets after $24 \mathrm{~h}$ and $72 \mathrm{~h}$ of immersion $(n=2$ for each) (Table 1) was used to calculate the protein intake, as follows:

$$
\operatorname{Protein} \operatorname{intake}(g)=\frac{(\text { protein content in diet } \times \text { food intake })}{100}
$$

The sea urchins in IC1 at the start of the experiment and those in the five treatments at the end of the experiment were dissected after TD and BW measurements were obtained. All gonads were removed, blotted on paper towel, weighed using an electronic balance ( $0.01 \mathrm{~g}$ accuracy), and stored at $-80^{\circ} \mathrm{C}$ for further analyses. The gonad index (GI) was calculated as follows:

$$
\mathrm{GI}=\text { gonad wet weight } \times \frac{100}{\mathrm{BW}} .
$$

Weekly increases in GI, daily food intake, daily protein intake, feed efficiency (FE), feed efficiency for gonad production $\left(\mathrm{FE}_{\text {gonad }}\right)$, protein efficiency $(\mathrm{PE})$, and protein efficiency for gonad production $\left(\mathrm{PE}_{\text {gonad }}\right)$ were calculated for each cage, as follows:

$$
\begin{gathered}
\text { Weekly increase in GI }=(\text { final GI }- \text { initial GI }) \times \frac{7}{\text { days }}, \\
\text { Daily food intake }(\%)=\frac{\text { food intake } \times 100}{[\text { days } \times((\text { final BW }+ \text { initial BW }) / 2)]}, \\
\text { Daily protein intake }(\%)=\frac{\text { protein intake } \times 100}{[\text { days } \times((\text { final BW }+ \text { initial BW }) / 2)]}, \\
\mathrm{FE}(\%)=(\text { final BW }- \text { initial BW }) \times \frac{100}{\text { food intake }}, \\
\mathrm{FE}_{\text {gonad }}(\%)=(\text { final GI }- \text { initial GI }) \times \frac{100}{\text { food intake }}, \\
\mathrm{PE}(\%)=(\text { final BW }- \text { initial BW }) \times \frac{100}{\text { protein intake }}, \\
\mathrm{PE}_{\text {gonad }}(\%)=(\text { final GI }- \text { initial GI }) \times \frac{100}{\text { protein intake }} .
\end{gathered}
$$


The water content in the gonad was determined for all individuals, including those in IC1, with the exception of 12 individuals whose gonad wet weight was $<1 \mathrm{~g}$ because of an insufficient sample amount. Approximately $1 \mathrm{~g}$ of frozen gonad tissue was weighed using an electric balance $(0.001 \mathrm{~g}$ accuracy), dried in an oven at $105^{\circ} \mathrm{C}$ for $24 \mathrm{~h}$, and then weighed again. The gonad water content, dry matter ratio, dry weight, dry matter gain, and weekly increase in the gonad dry matter index (weekly increase in GDI) were calculated as follows:

$$
\begin{aligned}
& \text { Gonad water content }(\%)=(\text { wet weight of gonad tissue } \\
& \text { - dry weight of gonad tissue) } \\
& \times \frac{100}{\text { wet weight of gonad tissue }} \text {, } \\
& \text { Gonad dry matter ratio }=\frac{\text { dry weight of gonad tissue }}{\text { wet weight of gonad tissue }}, \\
& \text { Gonad dry weight }(\mathrm{g})=\text { gonad wet weight } \\
& \times \text { gonad dry matter ratio, }
\end{aligned}
$$

$$
\begin{aligned}
\text { Gonad dry matter gain }(\mathrm{g})= & \text { final gonad dry weight } \\
& - \text { gonad dry weight in IC1, } \\
\text { Weekly increase in GDI = } & \frac{\text { final gonad dry weight }}{\text { final BW }} \\
& \left.-\frac{\text { gonad dry weight of IC1 }}{\text { BW of IC1 }}\right) \\
& \times \frac{7}{\text { days }} .
\end{aligned}
$$

For individuals whose gonad water content could not be measured, the gonad dry weight was calculated using the average gonad dry matter ratio for each treatment.

The gonad protein content was determined for six individuals from each group, specifically two urchins from each cage in the experimental groups and six urchins from the IC1 group. Selected individuals were those whose GI was close to the average of their cage or the average of the IC1 group. Details on the protein analysis are provided in Section 2.5. The gonad protein gain and protein retention were calculated as averages for each cage, as follows:

$$
\begin{gathered}
\text { Gonad protein gain }(\mathrm{g})=\frac{(\text { final gonad dry weight } \times \text { final gonad protein content }- \text { initial gonad dry weight } \times \text { initial gonad protein content })}{100}, \\
\text { Gonad protein retention }(\%) \text { = gonad protein gain } \times \frac{100}{\text { protein intake }} .
\end{gathered}
$$

The rearing water temperature measured every morning during the experiment was $13.4 \pm 0.2^{\circ} \mathrm{C}$ (mean \pm standard deviation $[\mathrm{SD}]$ ) in all tanks.

2.3.2. Experiment 2: STG Diets with 5-25\% Gluten (5\% Increments). Sea urchins were subjected to five feeding treatments with 50 -STG having $5 \%, 10 \%, 15 \%, 20 \%$, or $25 \%$ gluten (STG5, STG10, STG15, STG20, and STG25). This experiment was performed at the Central Fisheries Research Institute from June 25, 2021, to July 16, 2021 (21 days). Details on the diet composition are shown in Table 1. The diets were prepared in the same manner with the seawater immersion test as described in 2.1.

At the start of the experiment, 106 sea urchins (39$54 \mathrm{~mm}$ TD; 28-68 g BW) were divided into six groups: one for an initial control (IC2, 16 individuals) and the others for the feeding trials (18 individuals/treatment). Because the weight change ratio of the diets did not vary between samples immersed for $48 \mathrm{~h}$ and those immersed for $72 \mathrm{~h}$ in experiment 1 , food intake in this experiment was calculated based on the weight change ratio of the diets immersed for $48 \mathrm{~h}$. The other procedures were the same as those in experiment 1 . The rearing water temperature measured every morning during the experiment was $13.6 \pm 0.0^{\circ} \mathrm{C}$ (mean $\pm \mathrm{SD}$ ) in all tanks.

2.3.3. Experiment 3: STG Diets with 8-24\% Gluten (4\% Increments). Sea urchins were subjected to five feeding treatments with 50 -STG having $8 \%, 12 \%, 16 \%, 20 \%$, or $24 \%$ gluten (STG8, STG12, STG16, STG20, and STG24). This experiment was performed at Kushiro Field Station from May 7, 2021, to June 4, 2021 (28 days). Details on the diet composition are shown in Table 1 . The diets were prepared in the same manner with the seawater immersion test as described in 2.1 .

At the start of the experiment, 108 sea urchins (36$41 \mathrm{~mm}$ TD; 23-30 g BW) were divided into six groups. One group was an initial control (IC3, 18 individuals), and the other groups were intended for the feeding trial (18 individuals/treatment). Sea urchins were housed in cages in the 
same manner as in experiment 1 , although the specifications of the equipment slightly differed. The 15 cages were placed in three rectangular tanks (inside dimension, $\mathrm{L} 117 \times \mathrm{W} 78$ $\times \mathrm{H} 38 \mathrm{~cm}$ ) that were aerated and supplied with sandfiltered seawater maintained at approximately $13^{\circ} \mathrm{C}(3 \mathrm{~L} /$ $\mathrm{min} / \mathrm{tank}, 15 \mathrm{~cm}$ depth, flow-through system). The other procedures were the same as those in experiment 1 . The rearing water temperature measured every morning during the experiment was $12.9 \pm 0.6^{\circ} \mathrm{C}$ in one tank and $12.7 \pm$ $0.4^{\circ} \mathrm{C}$ in the others (mean $\pm \mathrm{SD}$ ).

2.4. Experiment 4: Feeding Trial with Alginate Diets. Sea urchins were subjected to five feeding treatments with 50ALG having $5 \%, 10 \%, 15 \%, 20 \%$, or $25 \%$ gluten (ALG5, ALG10, ALG15, ALG20, and ALG25). This experiment was performed at Kushiro Field Station from June 25, 2021, to July 19, 2021 (26 days). Details on the diet composition are shown in Table 1 . The diets were prepared in the same manner with the seawater immersion test as described in 2.1. The S. japonica used as the diet ingredient was collected from the Akkeshi Bay on April 26, 2021.

At the start of the experiment, 106 sea urchins (4048 mm TD; 30-52 g BW) were divided into six groups: one for initial control (IC4, 16 individuals) and the others for the feeding trial (18 individuals/treatment). Because the weight change ratio of the diets did not vary between samples immersed for $48 \mathrm{~h}$ and those immersed for $72 \mathrm{~h}$ in experiment 1 , food intake in this experiment was calculated based on the weight change ratio of the diets immersed for $48 \mathrm{~h}$. The other procedures were the same as those in experiment 3 . The rearing water temperature measured every morning during the experiment was $12.6 \pm 0.2^{\circ} \mathrm{C}$ in all tanks (mean $\pm \mathrm{SD})$.

2.5. Protein Content Determination. The nitrogen contents of the diet and gonad samples were analyzed using SUMIGRAPH (NC-TRINITY, Sumika Chemical Analysis Service, Ltd., Osaka, Japan) with aspartic acid as a standard for the immersion test and experiments 1-3, and using a CHN analyzer (Flash EA1112, Thermo Finnigan, CA, USA) with acetanilide as a standard for experiment 4, according to the combustion method. The gonad samples from experiment 3 were lyophilized and pulverized before analysis. The diet and gonad samples were thoroughly dried at $60^{\circ} \mathrm{C}$ for $48 \mathrm{~h}$ and $105^{\circ} \mathrm{C}$ for $24 \mathrm{~h}$, respectively, to remove the water remaining in the samples. The protein content in the diet and gonad samples was calculated by multiplying the nitrogen content by 6.25 .

2.6. Histological Observation. To confirm that the feeding experiments were completed before the start of the reproductive season, gonads of some animals in experiments 24 were subjected to histological observation at the end of the experiment. One individual was randomly selected from each cage, and a small piece (approximately $0.2 \mathrm{~g}$ ) of its gonad was fixed in Davidson's solution, dehydrated, and embedded in paraffin wax. Sections with a thickness of $10 \mu \mathrm{m}$ were prepared, dewaxed, stained with hematoxylin and eosin, and observed under a light microscope (BH-2,
Olympus Corporation, Tokyo, Japan). The gonadal maturities of the animals were classified into five stages according to Fuji [68] with some modifications [69], as follows: recovering (stage 1, before gametogenesis), growing (stage 2, early gametogenesis), premature (stage 3, mid-gametogenesis), mature (stage 4, late gametogenesis), and spent (stage 5, after spawning).

2.7. Statistical Analysis. Statistical analyses were conducted using $\mathrm{R}$ version 4.1.0 [70]. The data were tested for homogeneity of variance using Levene's test. Data that were not normally distributed or did not show homogeneity of variance were log-transformed. Significant differences in TD, BW, GI, and gonad dry weights of the sea urchins among the treatment groups were analyzed using nested one-way analysis of variance (ANOVA). Tukey's multiple comparison test was performed as a post hoc test on an individual basis for these parameters because the effects of cage and the treatment-cage interaction were undetected by nested ANOVA. Significant differences in the daily food intake, daily protein intake, FE, $\mathrm{FE}_{\text {gonad }}$, PE, $\mathrm{PE}_{\text {gonad }}$, weekly increase in GI, gonad dry matter gain, gonad protein gain, gonad water and protein contents, and gonad protein retention of sea urchins among treatments $\left(N_{\text {cage }}=3\right)$ were tested using Tukey's post hoc test.

To determine the dietary protein requirement for gonad production, the broken-line regression model, which is widely used to estimate nutrient requirements of animals, including fish (e.g., [71, 72]) and poultry (e.g., [73, 74]), and the quadratic regression model, which has previously been used to estimate the relationship between protein content and gonadal growth of sea urchins [59], were used to predict the relationship between the dietary protein content and the weekly increase in GDI in the STG diets (experiments 1-3). The model with the lowest sum of the Akaike information criterion (AIC) and Bayesian information criterion (BIC) scores was chosen for protein requirement estimation. To correct the effects of sea urchin conditions (e.g., body and gonad sizes) at the start of the feeding trials among the three experiments, the weekly increase in GDI for each cage was divided by the average weekly increase in GDI for the $20 \%$ gluten diet group of the same experiment, and this value was used as the GDI ratio during modeling. Regression analysis using the chosen model was also performed for each experiment (experiments 1-4).

\section{Results}

3.1. Shape Stability and Protein Leaching of Artificial Diets. After 72 h of immersion, 5-STG, 5-STC, 15-STG, 15-STC, 5-ALG, 5-ALC, and 50-STC-F had disintegrated, and 15ALG, 15-ALC, 5-AGG, 5-AGC, and 50-STG-F were partially broken (Figure S2). There were no visible changes in the shapes of 50-STG, 50-STC, 50-ALG, 50-ALC, 15-AGG, and 15-AGC. Overall, the protein content in the casein diets decreased with time. Specifically, $22-41 \%$ of the protein contained in the casein diets was lost after $72 \mathrm{~h}$ of immersion, regardless of the binder source and concentration. The exception was 50-STC, which retained 
$90 \%$ of its protein after $72 \mathrm{~h}$ of immersion (Figure S3). In contrast, the protein content in the gluten diets was relatively stable; more than $86 \%$ of the protein was retained in each of the gluten diets after $72 \mathrm{~h}$ of immersion. The protein retention in 50-STC-F was inferior to that in 50-STC.

3.2. Experiment 1. The survival rate at the end of the experiment was $100 \%$. The change in the protein content of the diets after seawater immersion was $<1.5$ percentage points (p.p.) for all treatments (Table 1). No significant differences in TD and BW among the treatments at the start and end of the experiment were detected with nested ANOVA (Tables 2 and S2). The GI, weekly increase in GI, gonad dry matter gain, water and protein contents, and gonad protein retention of STG0 were significantly lower than those of the other groups $(P<0.01)$, but there were no significant differences in these traits among STG10, STG20, STG30, and STG40 (Table 2 and Figure 1). The GI of each treatment increased from 4.0 in IC1 to 7.1 in STG0, to $>14$ in STG10 and STG40, and to $>16$ in STG20 and STG30. The gonad dry weight of STG20 was significantly higher than that of STG0 $(P<0.05)$. Gonad protein and dry matter gains increased with the increase in dietary gluten content from $0 \%$ to $30 \%$, but they decreased at $40 \%$. These results suggested that the dietary protein requirement for gonad production is between $1.5 \%$ (STG0) and 28.9\% (STG30). The water and protein contents in the gonads, daily protein intake, $\mathrm{FE}$, and $\mathrm{FE}_{\text {gonad }}$ increased with increasing dietary gluten content, whereas daily food intake and PE decreased. No significant differences in $\mathrm{PE}_{\text {gonad }}$ were detected among the treatments.

3.3. Experiment 2. Based on the results of experiment 1, experiment 2 was conducted with STG diets containing 5$25 \%$ gluten in $5 \%$ increments. The survival rate at the end of the experiment was $100 \%$. The change in the protein content of the diets after seawater immersion was $<1.6$ p.p. for all treatments (Table 1). No significant differences in TD, BW, and gonad dry weight were detected among the treatments with nested ANOVA (Tables 2 and S3). The GIs of STG15, STG20, and STG25 were significantly higher than those of STG5. There were no significant differences in protein content in the gonads and PE among the treatments. The gonad water content of the STG5 treatment was significantly lower than that of the other treatments $(P<0.05)$. The weekly increases in GI, gonad dry matter gain, and gonad protein gain for the STG15 treatment were significantly higher than those of STG5 $(P<0.05)$ (Figure 2$)$. These results further narrowed the possible range of the dietary protein requirement for gonad production to be between 4.6\% (STG5) and 17.3\% (STG20). Daily protein intake and $\mathrm{FE}_{\text {gonad }}$ increased with increasing dietary gluten content, whereas daily food intake decreased. The FE in the STG20 treatment and gonad protein retention in the STG10 were significantly higher than each of STG5, respectively $(P<0.05)$. The $\mathrm{PE}_{\text {gonad }}$ in the STG10 treatment was significantly higher than that in the STG25 $(P<0.05)$.
Among the 15 sea urchins that were subjected to histological observations after the feeding trial, nine were females and had stage-2 ovaries (Figure S4). Six individuals were males, three of which had stage- 1 or -2 testes. The testes of three males had proceeded to stage-3, but only a few sperm were observed, and the nutritive phagocytes remained predominant in the gonadal acini.

3.4. Experiment 3. Based on the results of experiment 2, experiment 3 was conducted with STG diets containing 8$24 \%$ gluten in $4 \%$ increments. The survival rate at the end of the experiment was $100 \%$. The changes in the protein content of the diets after seawater immersion were $<2.3$ p.p. in each treatment (Table 1). No significant differences in TD, BW, and gonad dry weight were detected among the treatments by nested ANOVA (Tables 2 and S4). There were no significant differences in the gonad protein content, weekly increase in GI, PE, and gonad protein and dry matter gains among treatments (Table 2 and Figure 3). The GI increased from 9.1 in IC 3 to $>20$ by the end of the experiment, and that of STG12, STG16, and STG20 were significantly higher than that of STG8 $(P<0.05)$. The water content in the gonads in the STG20 and STG24 treatments was significantly higher than that in STG8 $(P<0.05)$. The $\mathrm{PE}_{\text {gonad }}$ and gonad protein retention in the STG12 treatment were significantly higher than those of STG24 $(P<0.05)$. Daily food intake decreased with increasing dietary gluten content, whereas daily protein intake, $\mathrm{FE}$, and $\mathrm{FE}_{\mathrm{gonad}}$ increased.

Among the 15 sea urchins that were subjected to histological observations after the feeding trial, 10 individuals were female and 5 were male, all of which had stage- 1 or stage-2 gonads (Figure S4). No urchins produced gametes during the feeding trial.

3.5. Experiment 4. The survival rate at the end of the experiment was $100 \%$. The changes in the protein content of the diets after immersion were <1.4 p.p. in all treatments (Table 1). No significant differences in TD, BW, and gonad dry weight were detected among the treatments with nested ANOVA (Tables 2 and S5). The GI increased from 11.3 in IC4 to 14.6 in ALG5, to 17.1 in ALG10, and to $>18$ in ALG15, ALG20, and ALG25 (Table 2). The GI and weekly increase in GI of ALG5 were significantly lower than those of the other treatments $(P<0.05)$ (Table 2 and Figure 4$)$. There were no significant differences in gonad dry matter gain, $\mathrm{PE}_{\text {gonad }}$, water and protein contents, and gonad protein retention among treatments. Daily food intake decreased with increasing dietary gluten content, whereas daily protein intake, $\mathrm{FE}$, and $\mathrm{FE}_{\text {gonad }}$ increased. The PE of ALG5 was significantly higher than that of the other treatments $(P<0.05)$. The gonad protein gain in ALG10, ALG15, and ALG25 treatments were significantly higher than those in ALG5 $(P<0.05)$.

Among the 15 sea urchins that were subjected to histological observations after the feeding trial, six individuals were female and had stage- 1 or stage- 2 ovaries (Figure S4). Nine individuals were male, eight of which had stage-1 or stage- 2 testes. The testes of one male had proceeded to 


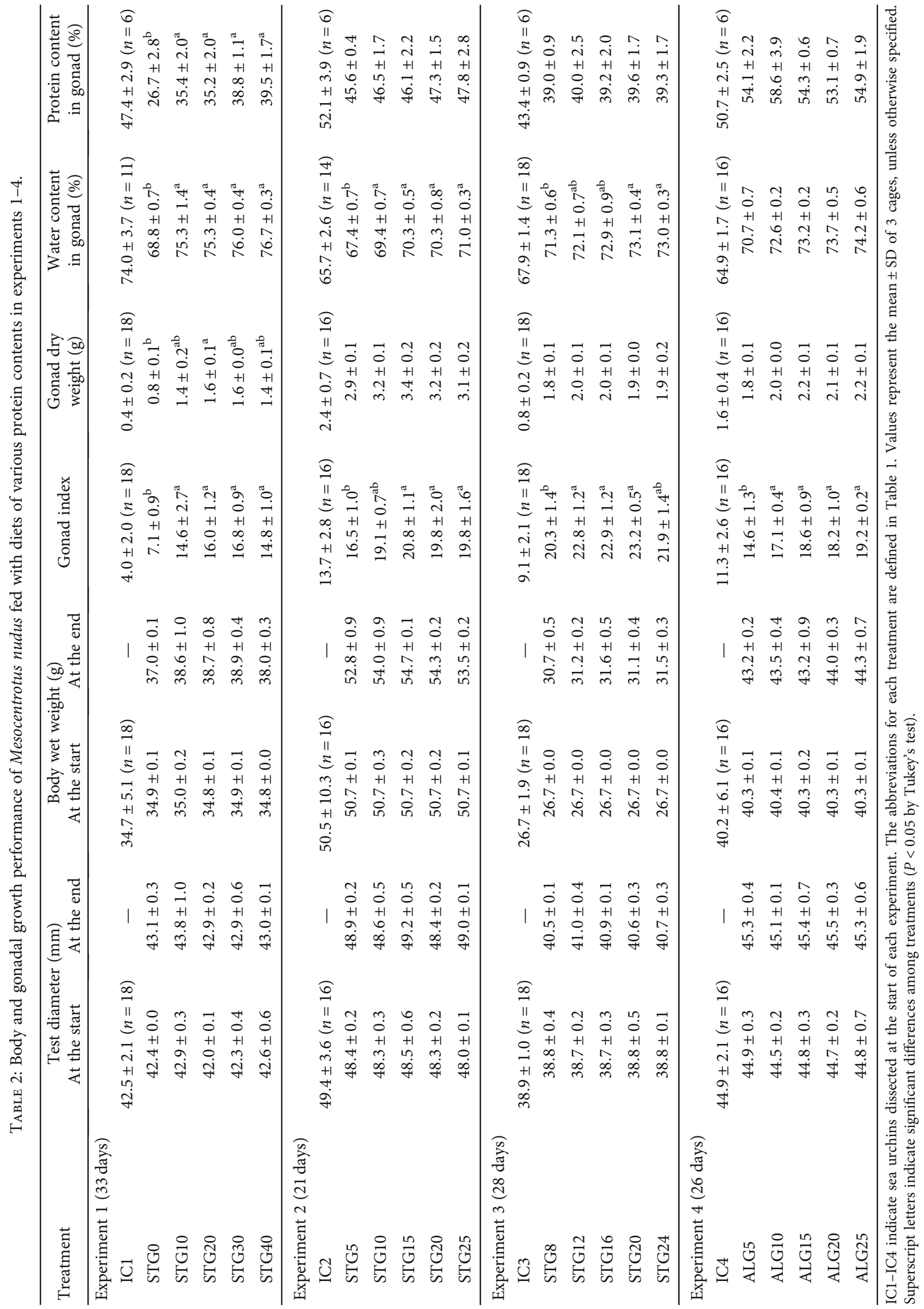




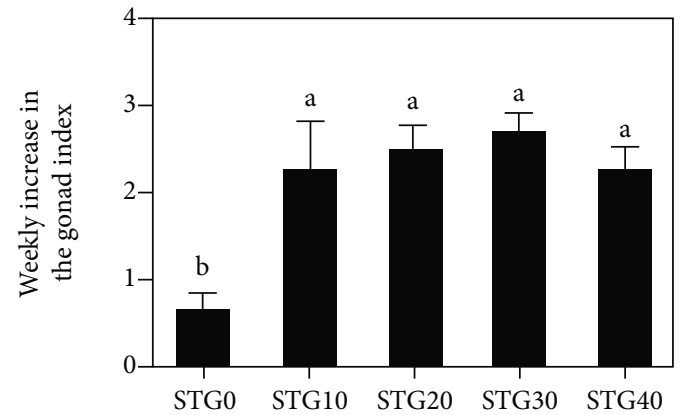

(a)

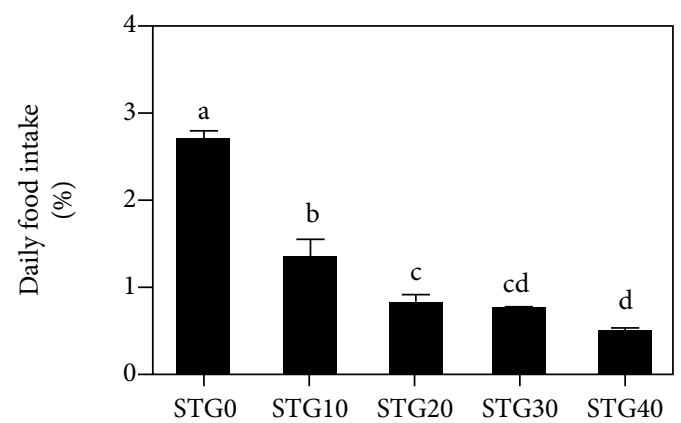

(c)

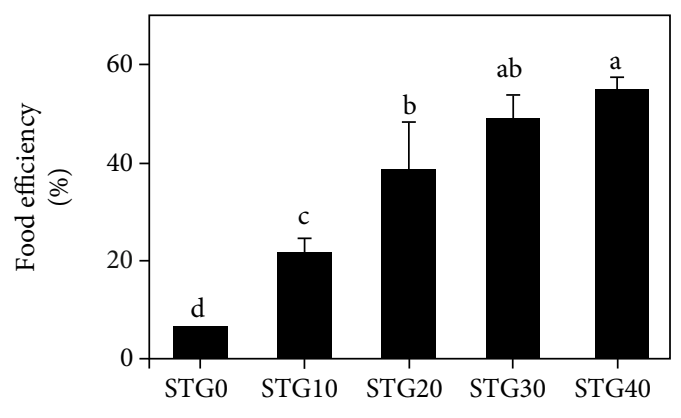

(e)

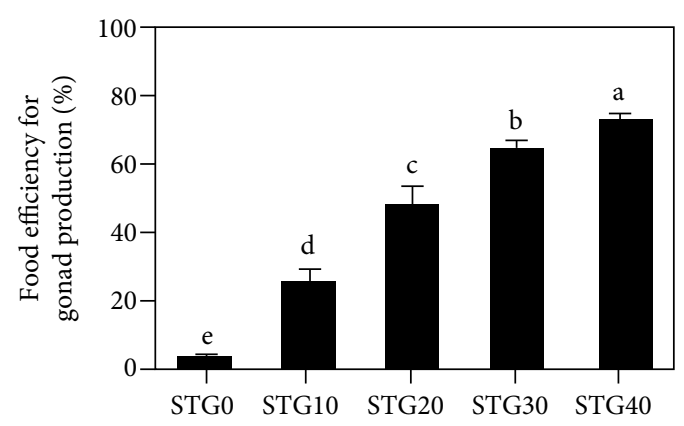

(g)

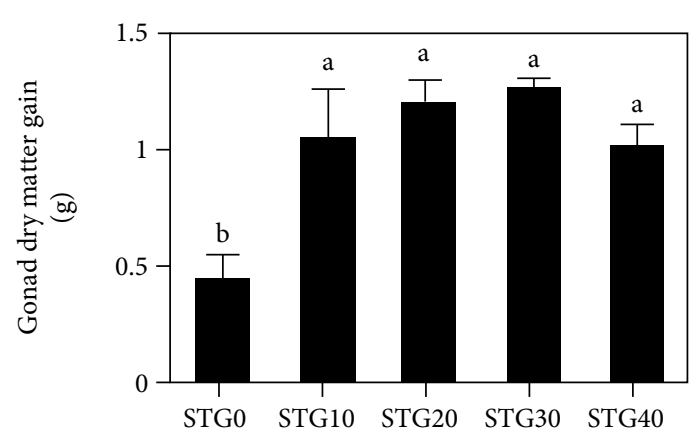

(b)

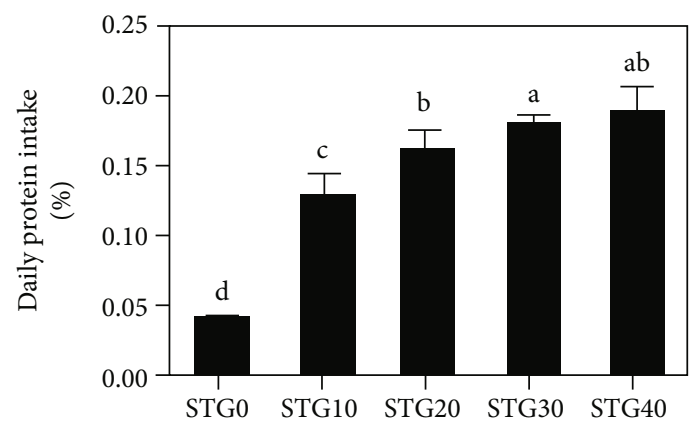

(d)

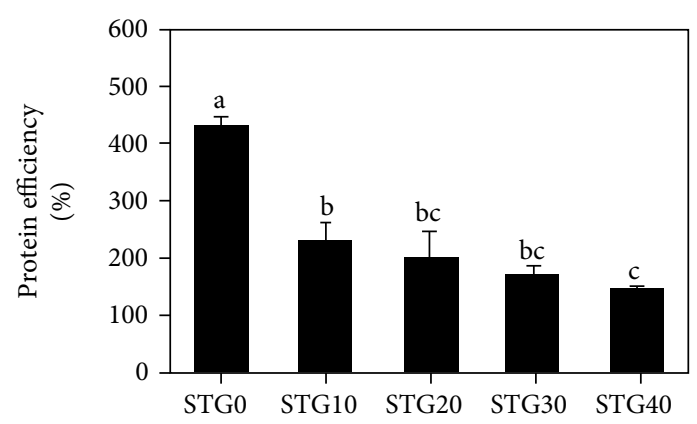

(f)

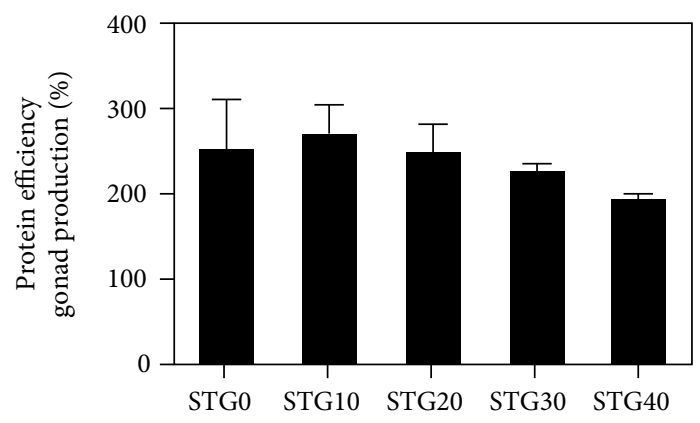

(h)

Figure 1: Continued. 


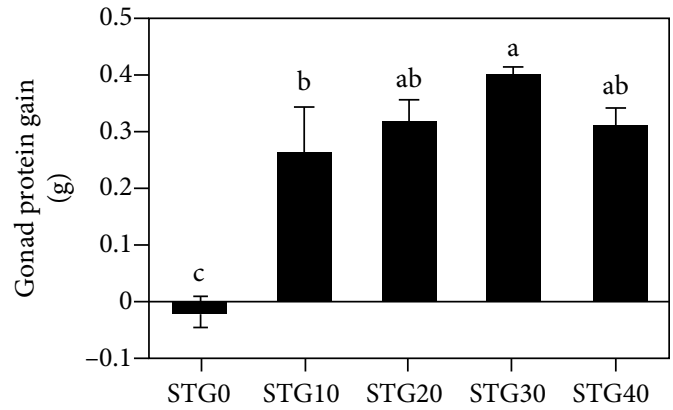

(i)

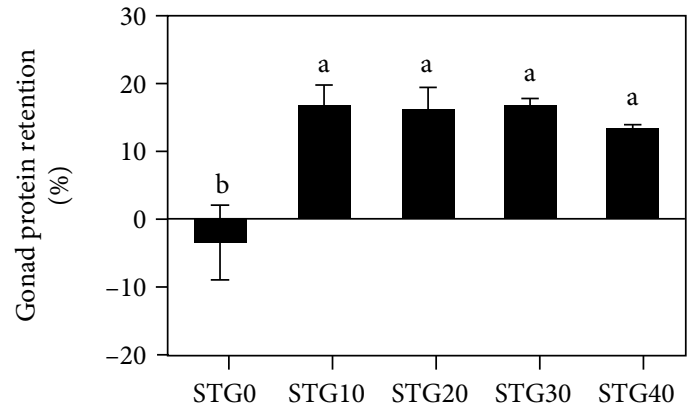

(j)

Figure 1: Gonadal growth performance and feed utilization of Mesocentrotus nudus fed diets containing $0-40 \%$ gluten with starch as a binder in experiment 1. (a) Weekly increase in the gonad index. (b) Gonad dry matter gain from the beginning to the end of the experiment (g). (c) Daily food intake (\%). (d) Daily protein intake (\%). (e) Food efficiency (\%). (f) Protein efficiency (\%). (g) Food efficiency for gonad production (\%). (h) Protein efficiency for gonad production (\%). (i) Gonad protein gain from the beginning to the end of the experiment (g). (j) Gonad protein retention (\%). The abbreviations for each treatment are defined in Table 1 . Values are means \pm standard deviations of three cages, each of which contained six sea urchins. Superscript letters indicate significant differences among treatments $(P<0.05$ by Tukey's test).

stage-3, but only a few sperm were observed, and the nutritive phagocytes remained predominant in the gonadal acini.

\subsection{The Dietary Protein Requirement for Gonad Production.} The sums of the AIC and BIC scores for the broken-line regression and quadratic models predicting the relationship between dietary protein content and the GDI ratio in STG diets were -30.4 and -11.1 , respectively. Thus, the brokenline model was chosen due to its better fit (Figure 5). The breakpoint indicating the dietary protein requirement for gonad production in the STG diets was estimated to be $11.7 \%$. The broken-line analyses performed for each experiment estimated the breakpoints of experiments 1, 2, and 3 as $13.0 \%, 11.7 \%$, and $11.7 \%$, respectively, although the intercept of each regression line was not significant. In ALG diets, the model estimated the breakpoint to be $10.5 \%$ without significance in the intercept of the regression line.

\section{Discussion}

In the feeding trials with low protein-leaching diets, whose protein content after seawater immersion was $<2.3$ p.p. lower than that before immersion, rapid gonad growth was observed for all sea urchins, including those fed diets with relatively low protein contents (Table 2; Figures 1-4). In experiments $1-3$, the optimum protein level for gonad production was estimated to be approximately $12 \%$ based on the broken-line regression analysis (Figure 5). Although the average body sizes of the sea urchins varied among the experiments (Table 2), the broken-line analysis for each experiment showed similar protein requirement levels (from $11.7 \%$ to $13.0 \%$ ), indicating that the body size did not affect the protein requirement estimation in the present study. In experiment 4 , the results of the broken-line regression analysis were not significant, but GI, gonad dry weight, weekly increase in GI, and the GDI ratio increased with the increase of dietary protein content from $4.5 \%$ (ALG5) to $12.0 \%$ (ALG15). All were similar among sea urchins fed diets with
12.0-21.1\% protein (ALG15, ALG20, and ALG25), indicating that protein content over $12 \%$ could not induce faster gonad growth in ALG diets. The estimated protein requirement was much lower than that reported in previous studies, which have typically reported a value of more than $20 \%$ (e.g., $[36,59])$, implying that the true protein requirement for sea urchin gonad production is rather modest when the problem of protein-leaching is addressed. The results of the histological observations ensured that all the feeding trials were conducted during the nonreproductive season with little influence of gamete production, which causes sexual dimorphism in the accumulation and consumption of nutrients in the gonads [75].

In the seawater immersion test, a higher shape stability of artificial diets was observed with increasing binder concentration (Figure S2). However, the shape stability of a diet does not always reflect its nutrient leaching capacity [63]. The present study showed that protein was leached during seawater immersion, even in diets that had not disintegrated such as 50-ALC, 15-ALC, and 15-AGC (Figure S3). Of the casein diets, only 50-STC retained more than $90 \%$ of its protein during seawater immersion, implying that starch has a better performance as a binder source than does alginate. In contrast to casein, gluten was scarcely lost from the diets, regardless of the binder source and concentration. Wheat gluten has a viscoelastic property that generates a network structure [76], and it can be used as a binder source for artificial diets [65]. Therefore, the use of wheat gluten as a protein source is a reasonable method for reducing protein leaching from diets due to its collateral effects as a binder. Of the frozen samples, 50-STG-F and 50-STC-F were partially disintegrated after seawater immersion, and a large amount $(37 \%)$ of protein was leached from 50-STC-F during immersion despite the high shape stability and protein retention in 50-STG and 50-STC. This diet deterioration caused by freezing may be attributed to structural changes associated with ice formation in the starch and gluten network during the freezing process [77]. Therefore, more 


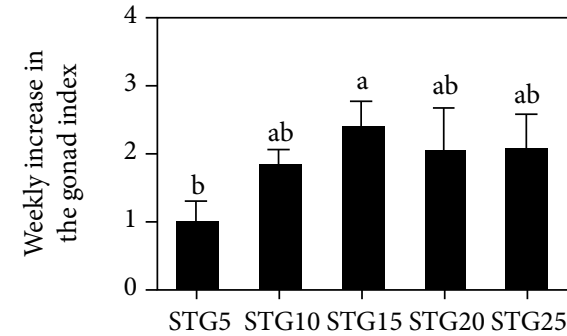

(a)

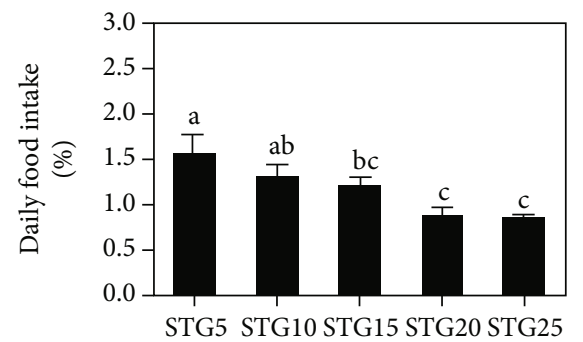

(c)

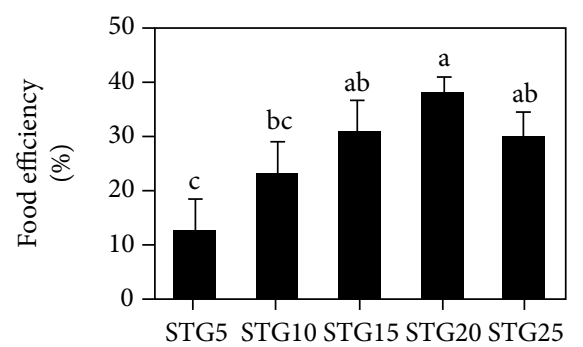

(e)

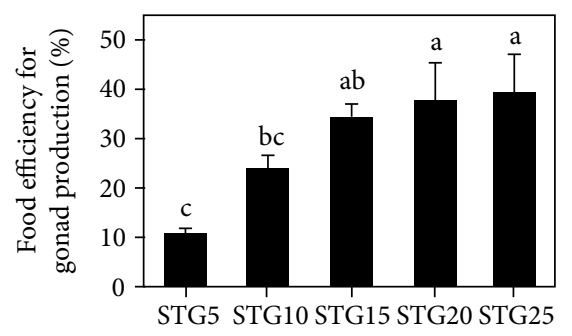

(g)

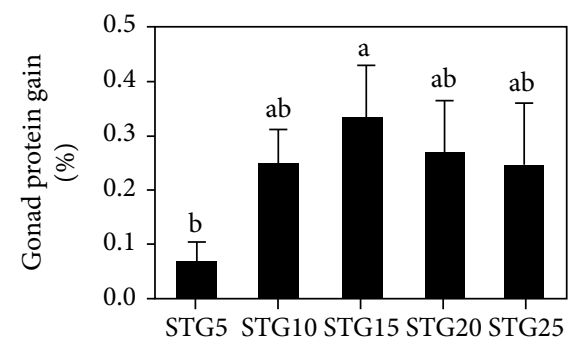

(i)

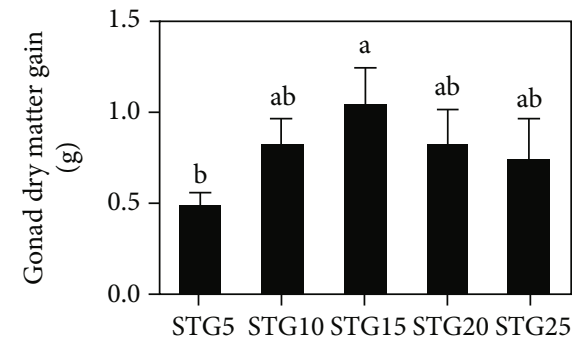

(b)

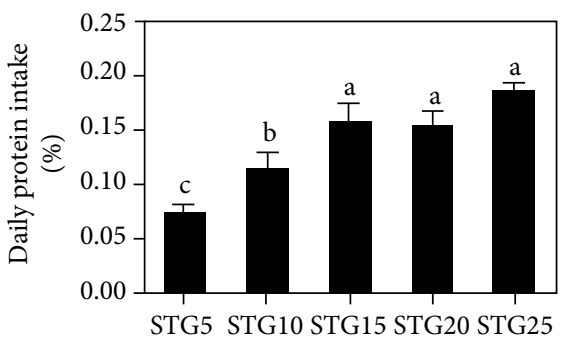

(d)

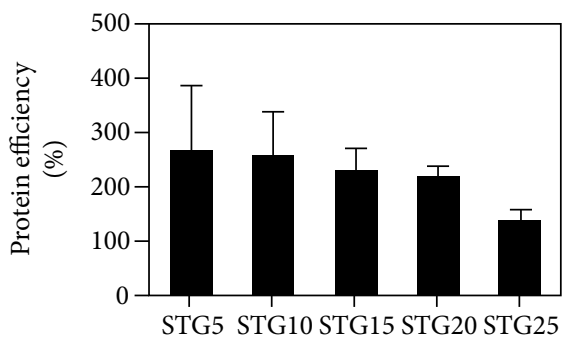

(f)

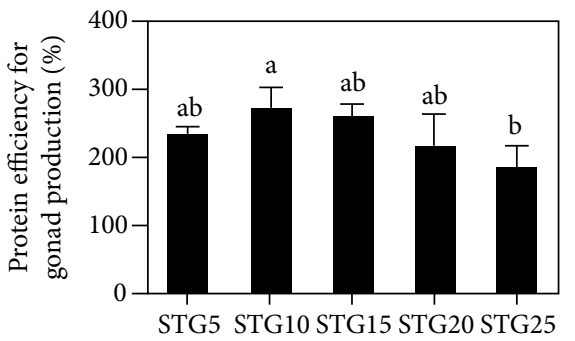

(h)

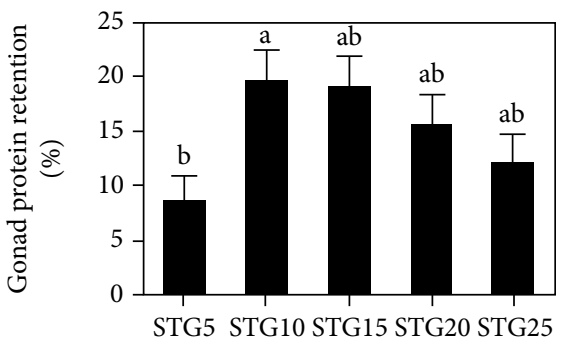

(j)

FIGURE 2: Gonad growth performance and feed utilization of Mesocentrotus nudus fed diets containing 5-25\% gluten with starch as a binder in experiment 2. (a) Weekly increase in the gonad index. (b) Gonad dry matter gain from the beginning to the end of the experiment (g). (c) Daily food intake (\%). (d) Daily protein intake (\%). (e) Food efficiency (\%). (f) Protein efficiency (\%). (g) Food efficiency for gonad production (\%). (h) Protein efficiency for gonad production (\%). (i) Gonad protein gain from the beginning to the end of the experiment (g). (j) Gonad protein retention (\%). The abbreviations for each treatment are defined in Table 1. Values are means \pm standard deviations of three cages, each of which contained six sea urchins. Superscript letters indicate significant differences among treatments $(P<0.05$ by Tukey's test). 


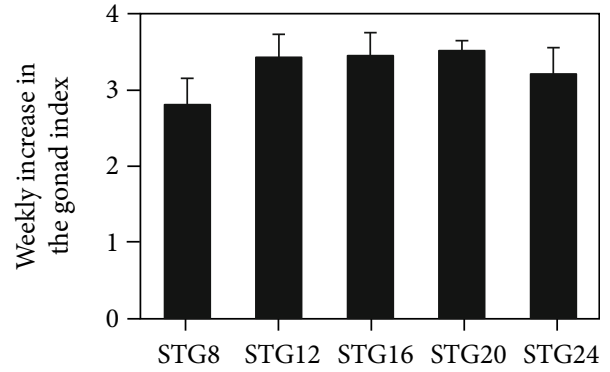

(a)

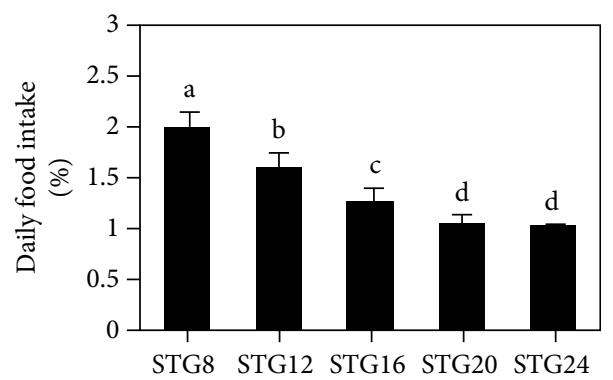

(c)

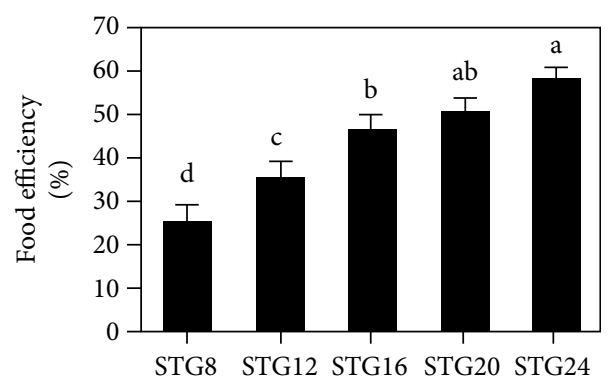

(e)

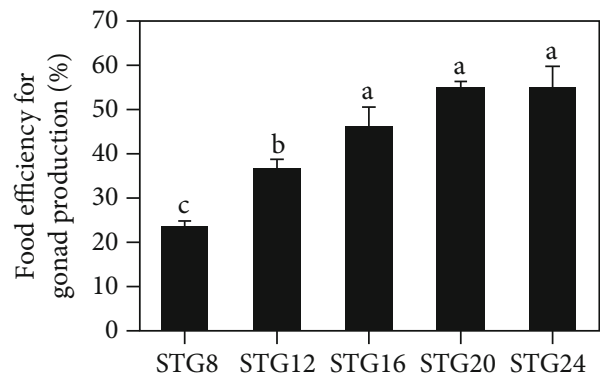

(g)

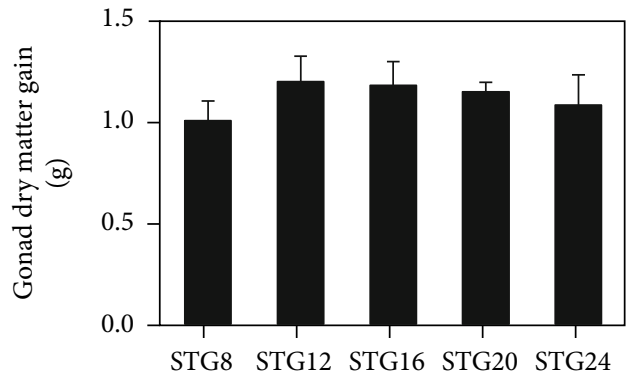

(b)

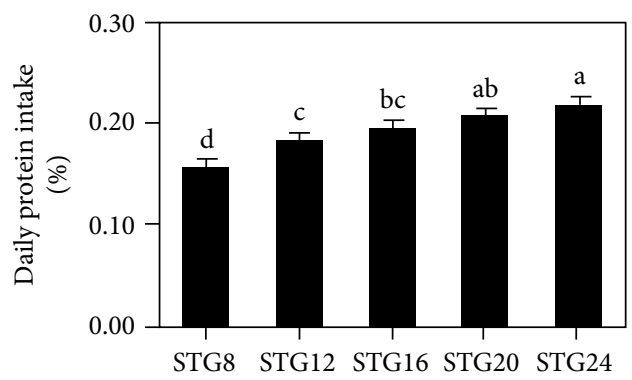

(d)

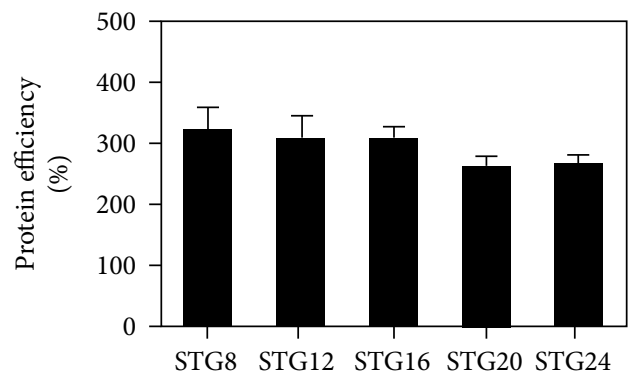

(f)

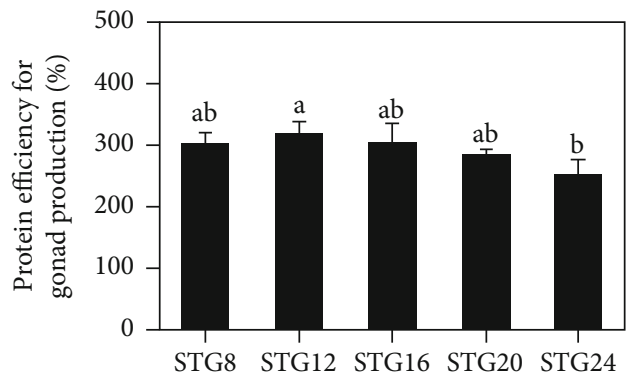

(h)

Figure 3: Continued. 


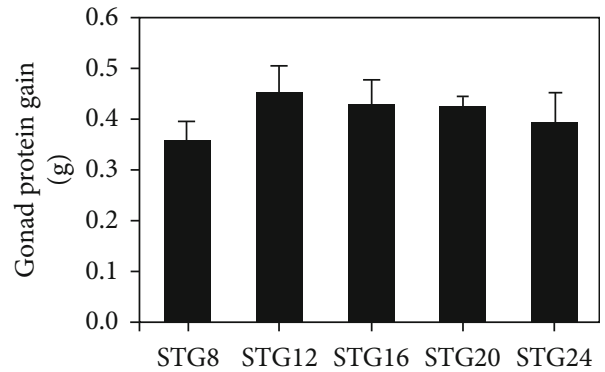

(i)

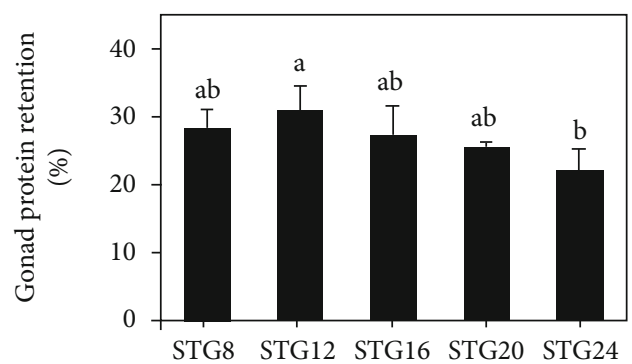

(j)

FIgURe 3: Gonad growth performance and feed utilization of Mesocentrotus nudus fed diets containing 8-24\% gluten with starch as a binder in experiment 3. (a) Weekly increase in the gonad index. (b) Gonad dry matter gain from the beginning to the end of the experiment (g). (c) Daily food intake (\%). (d) Daily protein intake (\%). (e) Food efficiency (\%). (f) Protein efficiency (\%). (g) Food efficiency for gonad production (\%). (h) Protein efficiency for gonad production (\%). (i) Gonad protein gain from the beginning to the end of the experiment (g). (j) Gonad protein retention (\%). The abbreviations for each treatment are defined in Table 1. Values are means \pm standard deviations of three cages, each of which contained six sea urchins. Superscript letters indicate significant differences among treatments $(P<0.05$ by Tukey's test).

attention should be paid to disintegration and nutrient leaching if the diets need to be frozen for a long storage period.

Protein is a vital macronutrient that is necessary for maintaining the physiological function of sea urchins [78]. Previous studies have shown an increase in the food intake of L. variagatus [35, 36], M. franciscanus [37], and $P$. lividus [59] with decreasing dietary protein, similar to that observed for $M$. nudus in the present study. This suggests that sea urchins consume large amounts of low-protein foods in an attempt to compensate for the lack of available protein in the diet [36]. Meanwhile, an increase in daily protein intake with increasing dietary protein was observed across the feeding trials, although Lourenço, José, Andrade, and Valente [59] reported that the protein intake of $P$. lividus was maintained at a certain level independent of dietary protein levels. Based on the data on M. nudus that were fed diets with protein contents near the optimum level (11-13\%), 0.16-0.18\% of the daily protein intake was estimated to be the required amount for gonad production. Despite the variation in daily food intake, there were no significant differences in BW among the treatments in each experiment. This resulted in an increase in the FE of $M$. nudus with increasing dietary protein content. Negative values of gonad protein gain and protein retention were observed in STG0 (1.5\% protein in the diet) in experiment 1 , suggesting that dietary protein deficiency was counteracted by the protein already stored in the gonads. An increase in the water content of M. nudus gonads was also observed with increasing dietary protein, which has previously been observed for L. variegatus [35, 57] and S. droebachiensis [46]. Since watery gonads are not preferred to sell to consumers [23], it is necessary to enhance the dry matter of gonads. Therefore, the present study estimated the protein requirement for gonad production on a dry-matter basis.

Numerous studies have shown a direct positive correlation between dietary protein level and gonad production in various sea urchin species by comparing artificial diets with $9-33 \%$ protein $[35,36,60,79-82]$. For $M$. nudus, the relationship between dietary protein and gonad production has not been previously investigated, although a positive correla- tion has been suggested based on comparisons between fish flesh [83, 84] or red algae [85] and Saccharina kelp. Heflin et al. [58] predicted that the dietary protein level most conducive for gonad production in young L. variegatus (approximately $3.95 \mathrm{~g} \mathrm{BW)} \mathrm{is} \mathrm{approximately} 30 \%$ on an $18 \%$ carbohydrate diet and approximately $35 \%$ on a $12 \%$ carbohydrate diet. Lourenço et al. [59] showed that a diet containing 30\% protein caused the greatest increase in the GI of small $P$. lividus (approximately $17 \mathrm{~g} \mathrm{BW)} \mathrm{by} \mathrm{comparing} \mathrm{six}$ experimental diets with $20-45 \%$ protein, although there were no significant differences among treatments. Akiyama et al. [44] reported that the optimum dietary protein content for gonad production of young $P$. depressus (approximately $1.6 \mathrm{~g} \mathrm{BW}$ ) was $30 \%$ by comparing five diets with $10-50 \%$ protein. The gonad indices of $M$. franciscanus (18.3 g BW) fed diets with $30 \%, 40 \%$, or $50 \%$ protein decreased with an increase in dietary protein [37]. The optimum protein level for gonad production of $S$. droebachiensis adults $(>50 \mathrm{~mm}$ TD) was suggested to be approximately $20-30 \%$ in previous studies $[46,60]$. The present study demonstrated that the optimum protein level in gluten-based diets for the gonad production of $M$. nudus adults is approximately $12 \%$ regardless of the binder source. This level is much lower than that reported in the previous studies mentioned above, but it nevertheless seems reasonable because edible sea urchins, including $M$. nudus, prefer to consume Laminariales kelp, which typically contain approximately $4-16 \%$ protein (e.g., $[61,62])$. To the best of our knowledge, no previous studies have addressed the problem of protein leaching in sea urchin diets. After seawater immersion, more than $30 \%$ of the protein was leached from certain casein diets (15-STC, 5-STC, 50-ALC, 15-AGC, and 50-STC-F). These results suggest the possibility that the optimum protein level of sea urchin diets has been overestimated in previous studies due to a gap in protein content between the designed value before feeding and the actual value after seawater immersion.

In most previous studies on the effect of dietary protein content on sea urchin gonad production, the concentrations of multiple ingredients were not kept consistent among experimental diets with different protein levels, despite knowledge that the protein source [86] and carbohydrate 


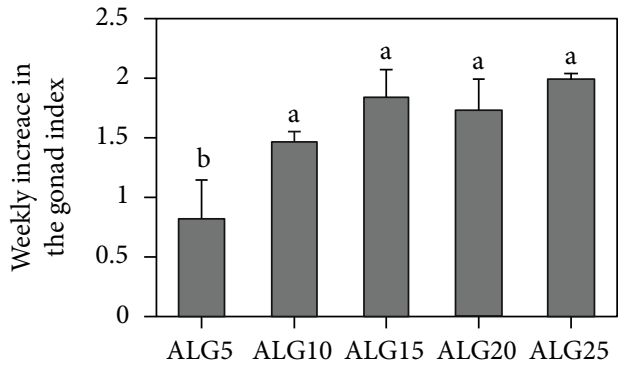

(a)

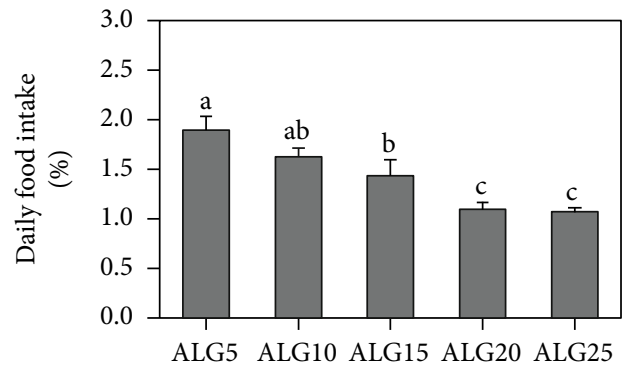

(c)

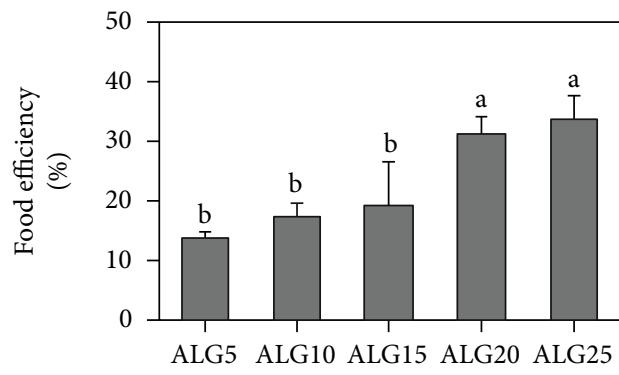

(e)

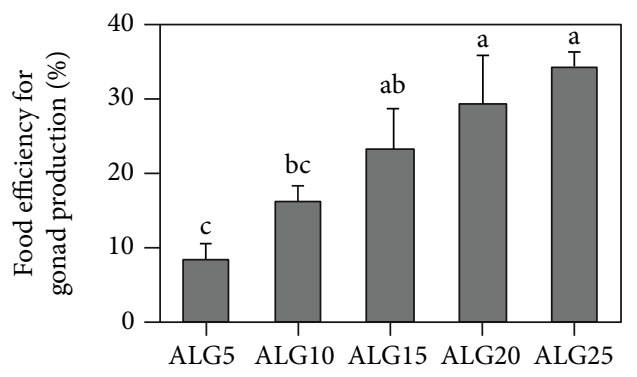

(g)

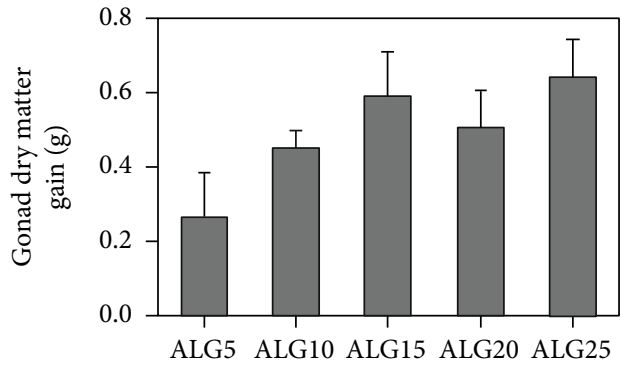

(b)

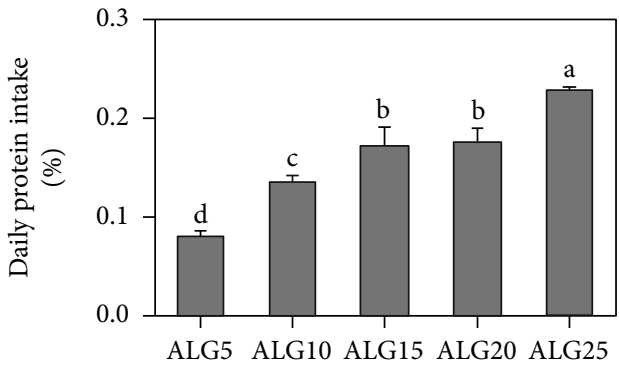

(d)

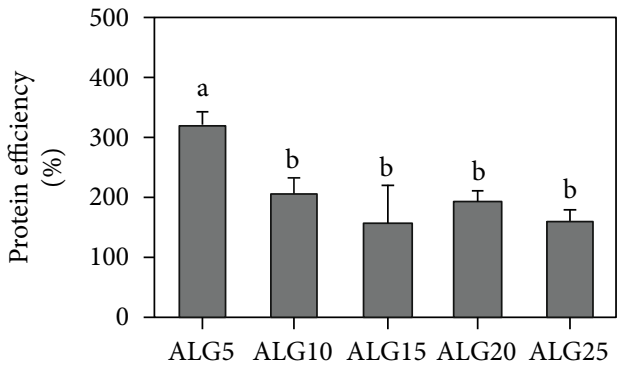

(f)

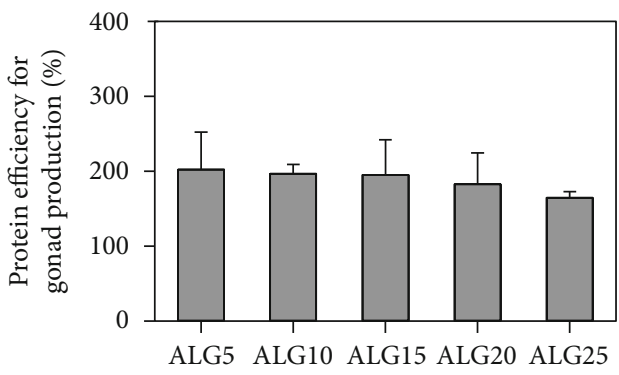

(h)

Figure 4: Continued. 


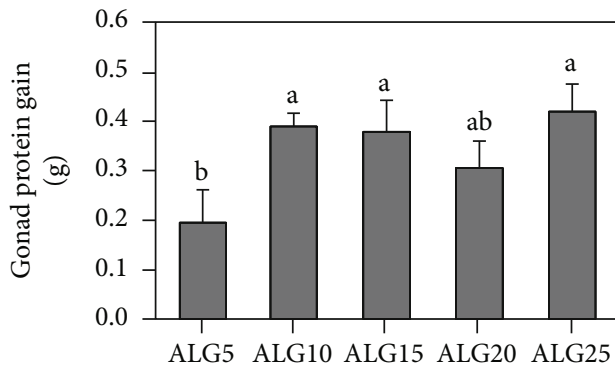

(i)

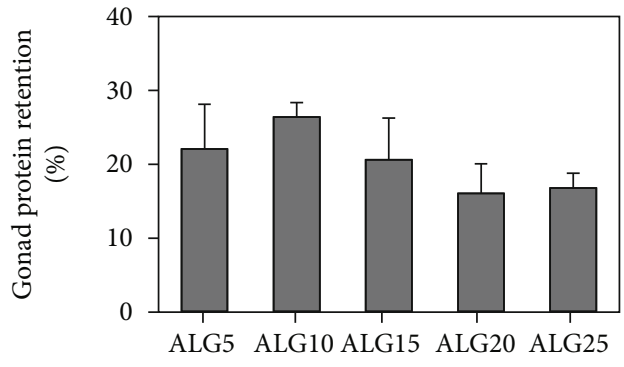

(j)

Figure 4: Gonad growth performance and feed utilization of Mesocentrotus nudus fed diets containing 5-25\% gluten with alginate as a binder in experiment 4. (a) Weekly increase in the gonad index. (b) Gonad dry matter gain from the beginning to the end of the experiment (g). (c) Daily food intake (\%). (d) Daily protein intake (\%). (e) Food efficiency (\%). (f) Protein efficiency (\%). (g) Food efficiency for gonad production (\%). (h) Protein efficiency for gonad production (\%). (i) Gonad protein gain from the beginning to the end of the experiment (g). (j) Gonad protein retention (\%). The abbreviations for each treatment are defined in Table 1. Values are means \pm standard deviations of three cages, each of which contained six sea urchins. Superscript letters indicate significant differences among treatments $(P<0.05$ by Tukey's test).

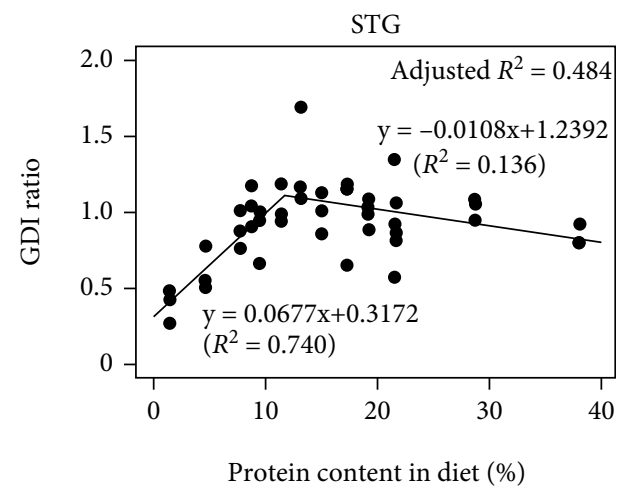

(a)

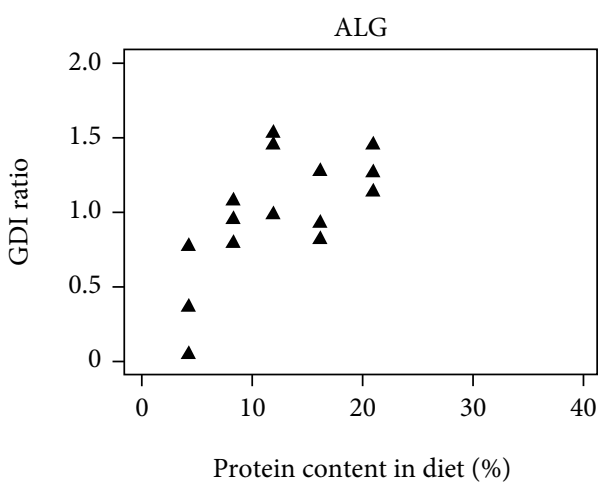

(b)

FIgURE 5: The relationship between the dietary protein content and the weekly increase in the gonad dry matter index (GDI) ratio of Mesocentrotus nudus fed with starch diets in experiments 1-3 (a) and alginate diets in experiment 4 (b). The GDI ratio indicates the standardized GDI across the experiments by dividing the value of each cage (three cages/diet) by the mean value of the $20 \%$ gluten group for each experiment. The broken line regression model (solid line) was used to estimate the optimal protein content from the results of the sea urchins fed starch diets (experiments 1-3).

and energy levels $[58,59]$ of a diet can affect gonad production. In feeding trials to investigate the dietary protein requirement of fish, cellulose, which is rarely digested by fish $[87,88]$, is usually used as a filler to adjust the diet composition without changing the contents of ingredients other than the protein source (e.g., $[89,90])$. Similarly, sea urchins seldom can digest cellulose because of their insufficient expression of cellulase genes [91] and limited cellulase activity [92]. Although the contribution of cellulolytic bacteria to cellulose digestion has been predicted in the wood-feeding sea urchin Asterechinus elegans [93], Watts et al. [94] considered that insoluble fiber (cellulose) is essentially not digested in sea urchins. Moreover, abundance of cellulase genes was rare $(<0.1 \%)$ in the metagenome sequences of the $M$. nudus gut microbe [95]. Thus, we used cellulose as a filler to balance diets with different protein contents to eliminate the effects of dietary contents other than protein. We hypothesize that cellulose is currently the best choice of filler to investigate the nutrient requirements of sea urchins. However, its influ- ence on nutrient absorption should be examined, as cellulose may be important for normal gut function and gut passage time for food [94].

The amino acid composition of diets is a significant factor affecting the dietary values of animal feed. Deficiency of essential amino acids (EAAs) in food has been shown to decrease growth in many fish species (e.g., [96, 97]). The amino acid composition of terrestrial plant-based ingredients is usually inferior to that of animal-based ingredients because some plant proteins do not contain sufficient amounts of certain EAAs (e.g., [98, 99]). Wheat gluten contains a lower level of lysine, an EAA for fish, than does fish meal (reviewed by [100]). For this reason, fish diets that use wheat gluten as a replacement protein source for fish meal require supplementation of lysine to compensate for amino acid imbalances (e.g., [96, 101]). Therefore, we cannot exclude the possibility that insufficient lysine content may have been a limiting factor for gonad growth in the present study, although neither the sea urchin EAAs nor 
the required level of each amino acid for gonad growth is known. If a protein source that has a better amino acid composition than wheat gluten is used as the main protein source for diets designed to minimize protein leaching, the optimum protein level for gonad production may shift to values lower than $12 \%$.

The weekly increase in GI of STG12-24 in experiment 3 was $>3$, which was markedly higher than that reported in previous studies that conducted feeding trials with $M$. nudus. For example, a weekly increase of 1.56 was reported for $M$. nudus fed sand lance (Ammodytes personatus) during November-December [84], 0.9 for that fed pacific saury (Cololabis saira) and arabesque greenling (Pleurogrammus azonus) during October-February [83], 1.5-1.9 for that fed a red alga (Pyropia yezoensis) during April-June [85], 1.5 for that fed S. japonica kelp frond during May-July [16], and 2.4 for that fed $U$. pinnatifida kelp sporophylls during May-July [24]. These examples indicate the high potential of STG diets for rapid gonad production.

\section{Conclusion}

The present study investigated the dietary protein requirement for $M$. nudus gonad production by addressing the problem of dietary protein leaching. In the feeding trials using STG and ALG diets with low disintegration and protein leaching, the dietary protein requirement for the gonad production of $M$. nudus adults was estimated to be approximately $12 \%$, which is much lower than that previously reported for various sea urchin species. The seawater immersion test revealed that a large amount of protein can leach from diets depending on the diet ingredients. This suggests that the previously reported protein requirement levels may have been estimated based on protein contents that were much higher than the actual value. Therefore, we think that nutrient leaching should be addressed to avoid overestimation of the required protein level. Our findings provide practical insight on how sea urchin diets can be developed to prevent wasting the protein source. Further studies are required to clarify whether this low dietary protein requirement is applicable to other protein sources and sea urchin species.

\section{Data Availability}

Raw data were generated at the Fisheries Resources Institute. The data that support the findings of this research are available from the corresponding author upon request.

\section{Conflicts of Interest}

The authors declare no conflicts of interest.

\section{Authors' Contributions}

Satomi Takagi did the conceptualization, methodology, software, validation, formal analysis, investigation, resources, data curation, writing-original draft, and visualization. Kazuhiro Takahashi did the conceptualization, methodol- ogy, investigation, resources, data curation, writing-review and editing, project administration, and funding acquisition. Tomonori Kaneta did the investigation and resources. Akira Sugawara did the conceptualization, methodology, and investigation. Masanao Narita did the investigation. Shinji Kato did the investigation. Masaki Akino did the investigation. Hirofumi Takeda did the investigation. Natsuki Hasegawa did the investigation, resources, and writing-review and editing. Yuji Machiguchi did the conceptualization and methodology. Tatsuya Unuma did the conceptualization, methodology, validation, resources, data curation, writing-review and editing, supervision, project administration, and funding acquisition.

\section{Acknowledgments}

We are grateful to Dr. Tomonori Azumaya of Kushiro Field Station, Fisheries Resources Institute, for helpful discussion on the model analyses to estimate protein requirement. We also thank Suzuko Tanaka and Yasuko Fuchigami of Kushiro Field Station, and Naomi Kasai and Junko Muraji of Central Fisheries Research Institute, for technical assistance throughout the study. This research was supported by the research program on development of innovative technology grants (JPJ007097) from the Project of the Bio-oriented Technology Research Advancement Institution (BRAIN) with grant number 01009B.

\section{Supplementary Materials}

Additional supporting information can be found in the online version of the article at the publisher's website. (Supplementary Materials)

\section{References}

[1] FAO, "Food Supply-Livestock and Fish Primary Equivalent," 2021, http://www.fao.org/faostat/en/\#data/CL/ visualize.

[2] OECD/FAO, OECD-FAO agricultural outlook 2019-2028, OECD publishing, Paris, 2019, France/food and agriculture Organization of the United Nations, Rome, Italy, accessed date: 2 July 2021.

[3] C. W. Walker, S. A. Bottger, T. Unuma et al., "Enhancing the commercial quality of edible sea urchin gonads-technologies emphasizing nutritive phagocytes," in Echinoderm Aquaculture, N. P. Brown and S. D. Eddy, Eds., pp. 263-286, Wiley Blackwell, Hoboken, USA, 2015.

[4] J. Sun and F. S. Chiang, "Use and exploitation of sea urchins," in Echinoderm Aquaculture, N. P. Brown and S. D. Eddy, Eds., pp. 25-45, Wiley Blackwell, Hoboken, USA, 2015.

[5] Metropolitan Central Wholesale Market, "Market Statistical Information," 2021, http://www.shijou-tokei.metro.tokyo.jp/.

[6] FAO, "Fishery Commodities and Trade," 2021, http://www .fao.org/fishery/statistics/global-commodities-production/ en.

[7] FAO, "Global Production, Fishery Statistical Collections," 2021, http://www.fao.org/fishery/statistics/globalproduction/en. 
[8] N. L. Andrew, Y. Agatsuma, E. Ballesteros et al., "Status and management of world sea urchin fisheries," Oceanography and Marine Biology: An Annual Review, vol. 40, pp. 343425, 2002.

[9] S. C. McBride, "Sea urchin aquaculture," American Fisheries Society Symposium, vol. 46, pp. 179-208, 2005.

[10] C. M. Pearce, "Introduction: sea-urchin aquaculture," Bulletin of the Aquaculture Association of Canada, vol. 108-1, pp. 1-2, 2010.

[11] R. A. Cameron and S. C. Schroeter, "Sea urchin recruitment: effect of substrate selection on juvenile distribution," Marine Ecology Progress Series, vol. 2, pp. 243-247, 1980.

[12] J. M. Lawrence, "On the relationships between marine plants and sea urchins," Oceanography and Marine Biology. Annual Review, vol. 13, pp. 213-286, 1975.

[13] Y. Agatsuma, M. Sato, and K. Taniguchi, "Factors causing brown-colored gonads of the sea urchin Strongylocentrotus nudus in northern Honshu, Japan," Aquaculture, vol. 249, pp. 449-458, 2005.

[14] C. Lang and K. H. Mann, "Changes in sea urchin populations after the destruction of kelp beds," Marine Biology, vol. 36, pp. 321-326, 1976.

[15] S. Takagi, Y. Murata, E. Inomata, H. Endo, M. N. Aoki, and Y. Agatsuma, "Improvement of gonad quality of the sea urchin Mesocentrotus nudus fed the kelp Saccharina japonica during offshore cage culture," Aquaculture, vol. 477, pp. 5061, 2017.

[16] S. Takagi, Y. Murata, E. Inomata, M. N. Aoki, and Y. Agatsuma, "Production of high quality gonads in the sea urchin Mesocentrotus nudus (A. Agassiz, 1864) from a barren by feeding on the kelp Saccharina japonica at the late sporophyte stage," Journal of Applied Phycology, vol. 31, pp. 40374048, 2019.

[17] T. Unuma, Y. Murata, N. Hasegawa, S. Sawaguchi, and K. Takahashi, "Improving the food quality of sea urchins collected from barren grounds by short-term aquaculture under controlled temperature," Bulletin of Fisheries Research Agency, vol. 40, pp. 145-153, 2015.

[18] C. G. Pert, S. E. Swearer, S. Dworjanyn et al., "Barrens of gold: gonad conditioning of an overabundant sea urchin," Aquaculture Environment Interactions, vol. 10, pp. 345-361, 2018.

[19] F. Warren-Myers, S. E. Swearer, D. S. Francis, G. M. Turchini, and T. Dempster, "Harvest method does not affect survival and condition during gonad enhancement of an overabundant sea urchin," Aquaculture Environment Interactions, vol. 11, pp. 143-148, 2019.

[20] F. Warren-Myers, G. Turchini, S. E. Swearer, D. Francis, and T. Dempster, "The balancing act: protein, lipid and seaweed dietary levels to maximize gonad quantity in a wild-caught sea urchin," Aquaculture Nutrition, vol. 27, pp. 1019-1030, 2021.

[21] P. James, T. Evensen, and A. Samuelsen, Commercial scale sea urchin roe enhancement in Norway: enhancement, transport and market assessment. Report 7/2017, Norway, Nofima, Troms $\varnothing, 2017$.

[22] A. L. Stranden, Norway's first onshore sea urchin farm up and running, ScienceNorway.no, Oslo, Norway, 2020, https:// sciencenorway.no/agriculture-and-fisheries-food-industry/ norways-first-onshore-sea-urchin-farm-up-and-running/ 1643267.
[23] T. Unuma, "Introduction: sea urchin fisheries in Japan," in Echinoderm Aquaculture, N. P. Brown and S. D. Eddy, Eds., pp. 77-85, Wiley Blackwell, Hoboken, USA, 2015.

[24] S. Takagi, Y. Murata, and Y. Agatsuma, "Feeding the sporophyll of Undaria pinnatifida kelp shortens the culture duration for the production of high-quality gonads of Mesocentrotus nudus sea urchins from a barren," Aquaculture, vol. 528, article 735503, 2020.

[25] D. M. Cuesta-Gomez and M. P. Sánchez-Saavedra, "Increased gonad growth of the purple sea urchin (Strongylocentrotus purpuratus) fed the giant kelp (Macrocystis pyrifera) and the sea lettuce (Ulva lactuca) enriched with nutrients," Aquaculture Research, vol. 47, pp. 2150-2163, 2016.

[26] S. Takagi, Y. Murata, E. Inomata, H. Endo, M. N. Aoki, and Y. Agatsuma, "Dietary effect of kelp (Saccharina japonica) on gonad quantity and quality in sea urchins (Mesocentrotus nudus) collected from a barren before the fishing season," Journal of Shellfish Research, vol. 37, pp. 659-669, 2018.

[27] S. Takagi, Y. Murata, T. Koshiishi, and Y. Agatsuma, "The amino acids glutamic acid and alanine in feed increase the alanine content in gonads of the sea urchin Mesocentrotus nudus," Frontiers in Marine Science, vol. 7, no. 593, 2020.

[28] J. Y. Li, Y. Murauchi, M. Ichinomiya, Y. Agatsuma, and K. Taniguchi, "Seasonal changes in photosynthesis and nutrient uptake in Laminaria japonica (Laminariaceae; Phaeophyta)," Aquaculture Science, vol. 55, pp. 587-597, 2007.

[29] J. Y. Li, Y. Agatsuma, T. Nagai, Y. Sato, and K. Taniguchi, "Differences in resource storage pattern between Laminaria longissima and Laminaria diabolica (Laminariaceae; Phaeophyta) reflecting their morphological characteristics," Journal of Applied Phycology, vol. 21, pp. 215-224, 2009.

[30] Y. Sato and Y. Agatsuma, "Resource accumulation of the kelp Saccharina ochotensis based on photosynthetic rate and specific nutrient uptake kinetics," Journal of Applied Phycology, vol. 28, pp. 499-509, 2016.

[31] K. Phillips, P. Bremer, P. Silcock et al., "Effect of gender, diet and storage time on the physical properties and sensory quality of sea urchin (Evechinus chloroticus) gonads," Aquaculture, vol. 288, pp. 205-215, 2009.

[32] K. Phillips, N. Hamid, P. Silcock et al., "Effect of manufactured diets on the yield, biochemical composition and sensory quality of Evechinus chloroticus sea urchin gonads," Aquaculture, vol. 308, pp. 49-59, 2010.

[33] M. Senaratna, L. H. Evans, L. Southam, and E. Tsvetnenko, "Effect of different feed formulations on feed efficiency, gonad yield and gonad quality in the purple sea urchin Heliocidaris erythrogramma," Aquaculture Nutrition, vol. 11, pp. 199-207, 2005.

[34] J. M. Lawrence, S. Olava, R. Otaiza, A. L. Lawrence, and E. Bustos, "Enhancement of gonad production in the sea urchin Loxechinus albus in Chile fed extruded feeds," Journal of the World Aquaculture Society, vol. 28, pp. 91-96, 1997.

[35] B. W. Hammer, H. S. Hammer, S. A. Watts, R. A. Desmond, J. M. Lawrence, and A. L. Lawrence, "The effects of dietary protein concentration on feeding and growth of small Lytechinus variegatus (Echinodermata: Echinoidea)," Marine Biology, vol. 145, pp. 1143-1157, 2004.

[36] H. Hammer, S. Watts, A. Lawrence, J. Lawrence, and R. Desmond, "The effect of dietary protein on consumption, survival, growth, and production of the sea urchin Lytechinus variegatus," Aquaculture, vol. 254, pp. 483-495, 2006. 
[37] S. C. McBride, J. M. Lawrence, A. L. Lawrence, and T. J. Mulligan, "The effect of protein content in prepared feeds on growth, feeding rate, total organic absorption, and gross assimilation efficiency of the sea urchin Strongylocentrotus franciscanus," Journal of Shellfish Research, vol. 17, pp. 1563-1570, 1998.

[38] S. C. McBride, J. M. Lawrence, A. L. Lawrence, and T. J. Mulligan, "Ingestion, absorption, and gonad production of adult Strongylocentrotus franciscanus fed different rations of a prepared diet," Journal of the World Aquaculture Society, vol. 30, pp. 364-370, 1999.

[39] S. C. McBride, R. J. Price, P. D. Tom, J. M. Lawrence, and A. L. Lawrence, "Comparison of gonad quality factors: color, hardness and resilience, of Strongylocentrotus franciscanus between sea urchins fed prepared feed or algal diets and sea urchins harvested from the northern California fishery," Aquaculture, vol. 233, pp. 405-422, 2004.

[40] E. J. Cook and M. S. Kelly, "Effect of variation in the protein value of the red macroalga Palmaria palmata on the feeding, growth and gonad composition of the sea urchins Psammechinus miliaris and Paracentrotus lividus (Echinodermata)," Aquaculture, vol. 270, pp. 207-217, 2007.

[41] E. J. Cook, A. D. Hughes, H. Orr, M. S. Kelly, and K. D. Black, "Influence of dietary protein on essential fatty acids in the gonadal tissue of the sea urchins Psammechinus miliaris and Paracentrotus lividus (Echinodermata)," Aquaculture, vol. 273, pp. 586-594, 2007.

[42] C. C. Suckling, R. C. Symonds, M. S. Kelly, and A. J. Young, "The effect of artificial diets on gonad colour and biomass in the edible sea urchin Psammechinus miliaris," Aquaculture, vol. 318, pp. 335-342, 2011.

[43] T. Akiyama, T. Unuma, T. Yamamoto, H. Furuita, and K. Konishi, "An evaluation of amino acid sources and binders in semipurified diet for red sea urchin Pseudocentrotus depressus," Fisheries Science, vol. 63, no. 6, pp. 881-886, 1997.

[44] T. Akiyama, T. Unuma, and T. Yamamoto, "Optimum protein level in a purified diet for young red sea urchin Pseudocentrotus depressus," Fisheries Science, vol. 67, pp. 361-363, 2001.

[45] C. M. Pearce, T. L. Daggett, and S. M. C. Robinson, "Effect of binder type and concentration on prepared feed stability and gonad yield and quality of the green sea urchin, Strongylocentrotus droebachiensis," Aquaculture, vol. 205, pp. 301-323, 2002.

[46] C. M. Pearce, T. L. Daggett, and S. M. C. Robinson, "Effect of protein source ratio and protein concentration in prepared diets on gonad yield and quality of the green sea urchin, Strongylocentrotus droebachiensis," Aquaculture, vol. 214, pp. 307-332, 2002.

[47] C. M. Pearce, T. L. Daggett, and S. M. C. Robinson, “Optimizing prepared feed ration for gonad production of the green sea urchin Strongylocentrotus droebachiensis," Journal of the World Aquaculture Society, vol. 33, pp. 268-277, 2002.

[48] Y. Q. Chang, J. M. Lawrence, X. B. Cao, and A. Lawrence, "Food consumption, absorption, assimilation and growth of the sea urchin Strongylocentrotus intermedius fed a prepared feed and the alga Laminaria japonica," Journal of the World Aquaculture Society, vol. 36, pp. 68-75, 2005.

[49] J. M. Lawrence, Y. Chang, X. Cao, A. L. Lawrence, and S. A. Watts, "Potential for production of uni by Strongylocentrotus intermedius using dry formulated feeds," Journal of the World Aquaculture Society, vol. 42, pp. 253-260, 2011.
[50] A. K. Azad, C. M. Pearce, and R. S. McKinley, "Effects of diet and temperature on ingestion, absorption, assimilation, gonad yield, and gonad quality of the purple sea urchin (Strongylocentrotus purpuratus)," Aquaculture, vol. 317, pp. 187-196, 2011.

[51] D. M. Cuesta-Gomez and M. P. Sánchez-Saavedra, "Effects of protein and carbohydrate levels on survival, consumption and gonad index in adult sea urchin Strongylocentrotus purpuratus (Stimpson 1857) from Baja California, Mexico," Aquaculture Research, vol. 48, pp. 1596-1607, 2017.

[52] M. D. Cyrus, J. J. Bolton, L. de Wet, and B. M. Macey, "The development of a formulated feed containing Ulva (Chlorophyta) to promote rapid growth and enhanced production of high quality roe in the sea urchin Tripneustes gratilla (Linnaeus)," Aquaculture Research, vol. 45, pp. 159-176, 2014.

[53] M. D. Cyrus, J. J. Bolton, R. Scholtz, and B. M. Macey, "The advantages of Ulva (Chlorophyta) as an additive in sea urchin formulated feeds: effects on palatability, consumption and digestibility," Aquaculture Nutrition, vol. 21, pp. 578-591, 2015.

[54] E. J. Cook, M. S. Kelly, and J. D. McKenzie, "Somatic and gonadal growth of the sea urchin Psammechinus miliaris (Gmelin) fed artificial salmon feed compared with a macroalgal diet," Journal of Shellfish Research, vol. 17, pp. 1549-1555, 1998.

[55] S. D. Eddy, N. P. Brown, A. L. Kling, S. A. Watts, and A. Lawrence, "Growth of juvenile green sea urchins, Strongylocentrotus droebachiensis, fed formulated feeds with varying protein levels compared with a macroalgal diet and a commercial abalone feed," Journal of the World Aquaculture Society, vol. 43, pp. 159-173, 2012.

[56] S. Olave, E. Bustos, J. M. Lawrence, and P. Cárcamo, "The effect of size and diet on gonad production by the Chilean sea urchin Loxechinus albus," Journal of the World Aquaculture Society, vol. 32, pp. 210-214, 2001.

[57] H. Hammer, B. Hammer, S. Watts, A. Lawrence, and J. Lawrence, "The effect of dietary protein and carbohydrate concentration on the biochemical composition and gametogenic condition of the sea urchin Lytechinus variegatus," Journal of Experimental Marine Biology and Ecology, vol. 334, pp. 109-121, 2006.

[58] L. E. Heflin, R. Makowsky, J. C. Taylor, M. B. Williams, A. L. Lawrence, and S. A. Watts, "Production and economic optimization of dietary protein and carbohydrate in the culture of juvenile sea urchin Lytechinus variegatus," Aquaculture, vol. 463, pp. 51-60, 2016.

[59] S. Lourenço, R. José, C. Andrade, and L. M. P. Valente, "Growth performance and gonad yield of sea urchin Paracentrotus lividus (Lamarck, 1816) fed with diets of increasing protein: energy ratios," Animal Feed Science and Technology, vol. 270, article 114690, 2020.

[60] M. de Jong-Westman, B. E. March, and T. H. Carefoot, "The effect of different nutrient formulations in artificial diets on gonad growth in the sea urchin Strongylocentrotus droebachiensis," Canadian Journal of Zoology, vol. 73, pp. 14951502, 1995.

[61] Y. Agatsuma, Y. Yamada, and K. Taniguchi, "Dietary effect of the boiled stipe of brown alga Undaria pinnatifida on the growth and gonadal enhancement of the sea urchin Strongylocentrotus nudus," Fisheries Science, vol. 68, pp. 1274-1281, 2002. 
[62] P. Schiener, K. D. Black, M. S. Stanley, and D. H. Green, "The seasonal variation in the chemical composition of the kelp species Laminaria digitata, Laminaria hyperborea, Saccharina latissima and Alaria esculenta," Journal of Applied Phycology, vol. 27, pp. 363-373, 2015.

[63] W. G. Dominy, J. J. Cody, J. H. Terpstra et al., “A comparative study of the physical and biological properties of commercially-available binders for shrimp feeds," Journal of Applied Aquaculture, vol. 14, pp. 81-99, 2003.

[64] E. Durazo-Beltrán and M. T. Viana, "Effect of the concentration of agar, alginate and carrageenan on the stability, toughness and nutrient leaching in artificial diets for abalone," Ciencias Marinas, vol. 27, pp. 1-19, 2001.

[65] W. Argüello-Guevara and C. Molina-Poveda, "Effect of binder type and concentration on prepared feed stability, feed ingestion and digestibility of Litopenaeus vannamei broodstock diets," Aquaculture Nutrition, vol. 19, pp. 515-522, 2013.

[66] T. A. Shipton and P. J. Britz, "The effect of animal size on the ability of Haliotis midae L. to utilize selected dietary protein sources," Aquaculture Research, vol. 32, pp. 393-403, 2001.

[67] Y. Agatsuma, "Ecological studies on the population dynamics of the sea urchin Strongylocentrotus nudus," Scientific Reports of Hokkaido Fisheries Experimental Station, vol. 51, pp. 1-66, 1997.

[68] A. Fuji, "Studies on the biology of the sea urchin. I. Superficial and histological gonadal changes in gametogenic process of two sea urchins, Strongylocentrotus nudus and S. intermedius," Bulletin of the Faculty of Fisheries Hokkaido University, vol. 11, pp. 1-14, 1960.

[69] T. Unuma, "Gonadal growth and its relationship to aquaculture in sea urchins," in The Sea Urchin: From Basic Biology to Aquaculture, pp. 115-127, Swets \& Zeitlinger, Lisse, Netherlands, 2002.

[70] R Core Team, R: A Language and Environment for Statistical Computing, R Foundation for Statistical Computing, Vienna, Austria, 2021, https://www.R-project.org/.

[71] F. E. Elesho, D. A. H. Sutter, M. A. C. Swinkels, J. A. J. Verreth, S. Kröckel, and J. W. Schrama, "Quantifying methionine requirement of juvenile African catfish (Clarias gariepinus)," Aquaculture, vol. 532, article 736020, 2021.

[72] Y. H. Lin, S. M. Lin, and S. Y. Shiau, "Dietary manganese requirements of juvenile tilapia, Oreochromis niloticus $\times O$. aureus," Aquaculture, vol. 284, pp. 207-210, 2008.

[73] D. E. Faria, R. H. Harms, and G. B. Russell, "Threonine requirement of commercial laying hens fed a corn-soybean meal diet," Poultry Science, vol. 81, pp. 809-814, 2002.

[74] M. Mehri, H. Nassiri-Moghaddam, H. Kermanshahi, and M. Danesh-Mesgaran, "Digestible lysine requirements of straight run broiler chickens from fifteen to twenty-eight days of age," Journal of Animal and Veterinary Advances, vol. 9, pp. 2321-2324, 2010.

[75] T. Unuma, T. Yamamoto, T. Akiyama, M. Shiraishi, and H. Ohta, "Quantitative changes in yolk protein and other components in the ovary and testis of the sea urchin Pseudocentrotus depressus," Journal of Experimental Biology, vol. 206, pp. 365-372, 2003.

[76] T. O. J. Blomfeldt, R. Kuktaite, E. Johnsson, and M. S. Hedenqvist, "Mechanical properties and network structure of wheat gluten foams," Biomacromolecules, vol. 12, pp. 1707-1715, 2011.
[77] A. Baier-Schenk, S. Handschin, M. von Schönau, A. G. Bittermann, T. Bächi, and B. Conde-Petit, "In situ observation of the freezing process in wheat dough by confocal laser scanning microscopy (CLSM): formation of ice and changes in the gluten network," Journal of Cereal Science, vol. 42, pp. 255-260, 2005.

[78] M. L. Powell, A. G. Marsh, and S. A. Watts, "Biochemical and energy requirements of gonad development in regular sea urchins," in Sea Urchin Biology and Ecology, J. M. Lawrence, Ed., pp. 51-64, Academic Press, Cambridge, USA, 4th edition, 2020.

[79] H. S. Hammer, M. L. Powell, W. T. Jones et al., "Effect of feed protein and carbohydrate levels on feed intake, growth, and gonad production of the sea urchin, Lytechinus variegatus," Journal of the World Aquaculture Society, vol. 43, pp. 145158, 2012.

[80] L. E. Heflin, V. K. Gibbs, M. L. Powell et al., "Effect of dietary protein and carbohydrate levels on weight gain and gonad production in the sea urchin Lytechinus variegatus," Aquaculture, vol. 358-359, pp. 253-261, 2012.

[81] E. Prato, G. Fanelli, A. Angioni et al., "Influence of a prepared diet and a macroalga (Ulva sp.) on the growth, nutritional and sensory qualities of gonads of the sea urchin Paracentrotus lividus," Aquaculture, vol. 493, pp. 240-250, 2018.

[82] C. M. C. Woods, P. J. James, G. A. Moss, J. Wright, and S. Siikavuopio, "A comparison of the effect of urchin size and diet on gonad yield and quality in the sea urchin Evechinus chloroticus Valenciennes," Aquaculture International, vol. 16, pp. 49-68, 2008.

[83] Y. Agatsuma, "Aquaculture of the sea urchin (Strongylocentrotus nudus) transplanted from coralline flats in Hokkaido, Japan," Journal of Shellfish Research, vol. 17, pp. 1541-1547, 1998.

[84] H. Hoshikawa, K. Takahashi, T. Sugimoto, K. Tuji, and S. Nobuta, "The effects of fish meal feeding on the gonad quality of cultivated sea urchins, Strongylocentrotus nudus (A. AGASSIZ)," Scientific Reports of Hokkaido Fisheries Experimental Station, vol. 52, pp. 17-24, 1998.

[85] E. Inomata, Y. Murata, T. Matsui, and Y. Agatsuma, "Gonadal production and quality in the sea urchin Mesocentrotus nudus fed a high-protein concentrated red alga Pyropia yezoensis," Aquaculture, vol. 454, pp. 184-191, 2016.

[86] S. Lourenço, B. Cunha, A. Raposo et al., "Somatic growth and gonadal development of Paracentrotus lividus (Lamarck, 1816) fed with diets of different ingredient sources," Aquaculture, vol. 539, article 736589, 2021.

[87] J. W. Hilton, J. L. Atkinson, and S. J. Slinger, "Effect of increased dietary fiber on the growth of rainbow trout (Salmo gairdneri)," Canadian Journal of Fisheries and Aquatic Sciences, vol. 40, pp. 81-85, 1983.

[88] R. Lesel, C. Fromageot, and M. Lesel, "Cellulose digestibility in grass carp, Ctenopharyngodon idella and in goldfish, Carassius auratus," Aquaculture, vol. 54, pp. 11-17, 1986.

[89] Z. Akpınar, H. Sevgili, T. Özgen, A. Demir, and Y. Emre, "Dietary protein requirement of juvenile shi drum, Umbrina cirrosa (L.)," Aquaculture Research, vol. 43, pp. 421-429, 2012.

[90] P. A. Ravan, R. H. Devlin, and D. A. Higgs, "Influence of dietary digestible energy content on growth, protein and energy utilization and body composition of growth hormone 
transgenic and non-transgenic coho salmon (Oncorhynchus kisutch)," Aquaculture, vol. 254, pp. 730-747, 2006.

[91] C. E. Trenzado, F. Hidalgo, D. Villanueva et al., "Study of the enzymatic digestive profile in three species of Mediterranean sea urchins," Aquaculture, vol. 344-349, pp. 174-180, 2012.

[92] K. Obrietan, M. Drinkwine, and D. C. Williams, "Amylase, cellulase and protease activities in surface and gut tissues of Dendraster excentricus, Pisaster ochraceus and Strongylocentrotus droebachiensis (Echinodermata)," Marine Biology, vol. 109, pp. 53-57, 1991.

[93] P. T. Becker, S. Samadi, M. Zbinden, C. Hoyoux, P. Compère, and C. De Ridder, "First insights into the gut microflora associated with an echinoid from wood falls environments," Cahiers de Biologie Marine, vol. 50, pp. 343-352, 2009.

[94] S. A. Watts, A. L. Lawrence, and J. M. Lawrence, "Nutrition," in Sea Urchin Biology and Ecology, J. M. Lawrence, Ed., pp. 191-208, Academic Press, Cambridge, USA, 4th edn edition, 2020.

[95] A. H. C. Haditomo, M. Yonezawa, J. Yu, S. Mino, Y. Sakai, and T. Sawabe, "The structure and function of gut microbiomes of two species of sea urchins, Mesocentrotus nudus and Strongylocentrotus intermedius, in Japan," Frontiers in Marine Science, vol. 8, 802754, 2021.

[96] S. J. Davies, P. C. Morris, and R. T. M. Baker, "Partial substitution of fish meal and full-fat soya bean meal with wheat gluten and influence of lysine supplementation in diets for rainbow trout, Oncorhynchus mykiss (Walbaum)," Aquaculture Research, vol. 28, pp. 317-328, 1997.

[97] M. J. Walton, C. B. Cowey, R. M. Coloso, and J. W. Adron, "Dietary requirements of rainbow trout for tryptophan, lysine and arginine determined by growth and biochemical measurements," Fish Physiology and Biochemistry, vol. 2, pp. 161-169, 1986.

[98] P. Gómez-Requeni, M. Mingarro, J. A. Calduch-Giner et al., "Protein growth performance, amino acid utilisation and somatotropic axis responsiveness to fish meal replacement by plant protein sources in gilthead sea bream (Sparus aurata)," Aquaculture, vol. 232, pp. 493-510, 2004.

[99] T. Watanabe, V. Verakunpiriya, K. Watanabe, V. Kiron, and S. Satoh, "Feeding of rainbow trout with non-fish meal diets," Fisheries Science, vol. 63, pp. 258-266, 1997.

[100] E. Apper-Bossard, A. Feneuil, A. Wagner, and F. Respondek, "Use of vital wheat gluten in aquaculture feeds," Aquatic Biosystems, vol. 9, article 21, p. 21, 2013.

[101] T. Yamamoto, T. Shima, H. Furuita, N. Suzuki, F. J. SánchezVázquez, and M. Tabata, "Self-selection and feed consumption of diets with a complete amino acid composition and a composition deficient in either methionine or lysine by rainbow trout, Oncorhynchus mykiss (Walbaum)," Aquaculture Research, vol. 32, pp. 83-91, 2001. 